\title{
Perimenopause and Postmenopause - Diagnosis and Interventions. Guideline of the DGGG and OEGGG (S3-Level, AWMF Registry Number 015-062, September 2020)
}

\author{
Peri- und Postmenopause - Diagnostik und Interventionen. \\ Leitlinie der DGGG und OEGGG (S3-Level, AWMF-Registernummer \\ 015-062, September 2020)
}

Authors

Elisabeth C. Inwald ${ }^{1}$, Christian Albring ${ }^{2}$, Erika Baum ${ }^{3}$, Maria Beckermann ${ }^{4}$, Kai J. Bühling ${ }^{5}$, Günter Emons ${ }^{6}$, Thomas Gudermann7 , Peyman Hadji ${ }^{8}$, Bruno Imthurn ${ }^{9}$, Ludwig Kiesel ${ }^{10}$, David Klemperer ${ }^{11}$, Petra Klose ${ }^{12}$, Klaus König ${ }^{13}$, Stephanie Krüger ${ }^{14}$, Jost Langhorst ${ }^{15}$, Michael Leitzmann ${ }^{16}$, Albert Ludolph ${ }^{17}$, Diana Lüftner ${ }^{18}$, Dorothea Müller ${ }^{19}$, Joseph Neulen ${ }^{20}$, Monika Nothacker ${ }^{21}$, Eckhard Petri $\dagger^{22}$, Horst Prautzsch ${ }^{23}$, Vera Regitz-Zagrosek ${ }^{24}$, Kathrin Schaudig ${ }^{25}$, Florian Schütz ${ }^{26}$, Anneliese Schwenkhagen ${ }^{25}$, Thomas Strowitzki ${ }^{27}$, Petra Stute ${ }^{28}$, Bettina-Maria Taute ${ }^{29}$, Clemens Tempfer ${ }^{30}$, Christine v. Arnim ${ }^{31}$, Ludwig Wildt ${ }^{32}$, Eberhard Windler ${ }^{33}$, Olaf Ortmann ${ }^{1}$

Affiliations

1 Klinik für Frauenheilkunde und Geburtshilfe, Lehrstuhl der Universität Regensburg, Caritas-Krankenhaus St. Josef, Regensburg, Germany; Leitlinienkoordinator(in)

2 Frauenarzt, Präsident des Berufsverbandes der Frauenärzte e. V., Frauenärzte im Netz, Hannover, Germany

3 Abteilung für Allgemeinmedizin, Präventive und Rehabilitative Medizin, Philipps Universität Marburg, Marburg, Germany

4 Frauenärztin, delegiert von der Deutschen Gesellschaft für Psychosomatische Frauenheilkunde und Geburtshilfe (DGPFG) e. V., Köln, Germany

5 Leiter der Hormonsprechstunde, Klinik und Poliklinik für Gynäkologie, Universitätsklinikum Hamburg-Eppendorf, Hamburg, Germany

6 Klinik für Gynäkologie und Geburtshilfe, Universitätsmedizin Göttingen, Göttingen, Germany

7 Walther-Straub-Institut für Pharmakologie und Toxikologie, Medizinische Fakultät, Ludwig-Maximilians-Universität München, München, Germany

8 Frankfurter Hormon und Osteoporosezentrum, Frankfurt am Main; Phillips-Universität Marburg, Marburg, Germany

9 Universitätsspital Zürich, Klinik für ReproduktionsEndokrinologie, Zürich, Switzerland

10 Universitätsklinikum Münster, Klinik für Frauenheilkunde und Geburtshilfe, Direktor, Münster, Germany

11 Ostbayerische Technische Hochschule Regensburg, Fakultät Angewandte Sozial- und Gesundheitswissenschaften, Regensburg, Germany

12 Kliniken Essen-Mitte, Knappschafts-Krankenhaus, Klinik für Naturheilkunde und Integrative Medizin, Essen, Germany

13 Stimmberechtigter Vertreter des Berufsverbandes der Frauenärzte, Eschborn, Germany

14 Department für seelische Gesundheit, Vivantes Klinikum Spandau, Berlin, Germany
15 Stiftungslehrstuhl für Integrative Medizin der Universität Duisburg-Essen, Chefarzt, Klinik für Integrative Medizin und Naturheilkunde, Sozialstiftung Bamberg, Klinikum am Bruderwald, Bamberg, Germany

16 Universitätsklinikum Regensburg, Fakultät für Medizin, Institut für Epidemiologie und Präventivmedizin, Regensburg, Germany

17 Universitätsklinikum Ulm, Klinik für Neurologie, Ulm, Germany

18 Klinik für Hämatologie, Onkologie und Tumorimmunologie, Charité - Universitätsmedizin, Berlin, Germany

19 Frauenselbsthilfe nach Krebs, Fulda, Germany

20 Uniklinik RWTH Aachen, Klinik für Gynäkologische Endokrinologie und Reproduktionsmedizin, Aachen, Germany

21 Arbeitsgemeinschaft der Wissenschaftlichen Medizinischen Fachgesellschaften (AWMF), Berlin, Germany

22 Arbeitsgemeinschaft für Urogynäkologie und plastische Beckenbodenrekonstruktion (AGUB), Schwerin; Germany; verstorben am 21.09.2019

23 Überörtliche Gemeinschaftspraxis, Facharzt für Allgemeinmedizin, Akademische Lehrpraxis der Universität Tübingen, Tübingen, Germany

24 Charité - Universitätsmedizin Berlin, Institut für Geschlechterforschung in der Medizin, Gender in Medicine (GiM), Berlin, Germany

25 Hormone Hamburg, Praxis für gynäkologische Endokrinologie, Hamburg, Germany

26 Klinik für Gynäkologie und Geburtshilfe am DiakonissenStiftungskrankenhaus Speyer, Speyer, Germany

27 Abteilung für Gynäkologische Endokrinologie und Fertilitätsstörungen, Frauenklinik, Universitätsklinikum Heidelberg, Heidelberg, Germany

28 Universitätsklinik für Frauenheilkunde, Inselspital Bern, Bern, Switzerland 
29 Universitätsklinikum Halle, Schwerpunktbereich Angiologie der Klinik für Innere Medizin III, Halle, Germany

30 Frauenklinik der Ruhr Universität Bochum, Marienhospital Herne, Bochum/Herne, Germany

31 Abteilung und Lehrstuhl für Geriatrie, Universitätsmedizin Göttingen, Göttingen, Germany

32 Em Direktor der Universitätsklinik für Gynäkologische Endokrinologie und Reproduktionsmedizin, Vorsitzender der Ethikkommission, Medizinische Universität Innsbruck, Innsbruck, Austria

33 Institut für Versorgungsforschung in der Dermatologie und bei Pflegeberufen (IVDP), Universitätsklinikum Hamburg-Eppendorf, Hamburg, Germany

\section{Key words}

perimenopause, postmenopause, hormone (replacement)

therapy, diagnosis, therapy, cancer risk, guideline

Schlüsselwörter

Perimenopause, Postmenopause, Hormon(ersatz-)therapie, Diagnostik, Interventionen, Krebsrisiko, Leitlinie

$\begin{array}{ll}\text { received } & 15.1 .2021 \\ \text { accepted after revision } & 18.1 .2021 \\ \text { published online } & 2.6 .2021\end{array}$

Bibliography

Geburtsh Frauenheilk 2021; 81: 612-636

DOI 10.1055/a-1361-1948

ISSN 0016-5751

(C) 2021. Thieme. All rights reserved.

Georg Thieme Verlag KG, Rüdigerstraße 14,

70469 Stuttgart, Germany

Correspondence

Prof. Dr. med. Olaf Ortmann

Ärztlicher Direktor, Direktor der Klinik für Frauenheilkunde und Geburtshilfe, Lehrstuhl der Universität Regensburg,

Caritas-Krankenhaus St. Josef

Landshuter Straße 65, 93053 Regensburg, Germany

olaf.ortmann@klinik.uni-regensburg.de

www.caritasstjosef.de

\section{ABSTRACT}

Aim The aim of the interdisciplinary S3-guideline Perimenopause and Postmenopause - Diagnosis and Interventions is to provide help to physicians as they inform women about the physiological changes which occur at this stage of life and the treatment options. The guideline should serve as a basis for decisions taken during routine medical care. This short version lists the statements and recommendations given in the long version of the guideline together with the evidence levels, the level of recommendation, and the strength of consensus.

Methods The statements and recommendations are largely based on methodologically high-quality publications. The literature was evaluated by experts and mandate holders using evidence-based medicine (EbM) criteria. The search for evidence was carried out by the Essen Research Institute for Medical Management (EsFoMed). To some extent, this guideline also draws on an evaluation of the evidence used in the NICE guideline on Menopause and the S3-guidelines of the AWMF and has adapted parts of these guidelines.

Recommendations Recommendations are given for the following subjects: diagnosis and therapeutic interventions for perimenopausal and postmenopausal women, urogynecology, cardiovascular disease, osteoporosis, dementia, depression, mood swings, hormone therapy and cancer risk, as well as primary ovarian insufficiency.

\section{ZUSAMMENFASSUNG}

Ziel Ziel der interdisziplinären S3-Leitlinie „Peri- und Postmenopause - Diagnostik und Interventionen“ ist es, Ärzte bei der Aufklärung von Frauen über die physiologischen Veränderungen in dieser Lebensphase sowie Therapiemöglichkeiten zu unterstützen. Die Leitlinie soll eine Entscheidungsgrundlage im ärztlichen Alltag darstellen. In der vorliegenden Kurzversion werden die Statements und Empfehlungen der Langversion mit Evidenzgrad, Empfehlungsgrad und Konsensusstärke aufgeführt.

Methoden Die Statements und Empfehlungen basieren überwiegend auf methodisch hochwertigen Publikationen. Es erfolgte eine Bewertung der Literatur nach den Kriterien der evidenzbasierten Medizin (EbM) durch Experten und Mandatsträger. Die Evidenzrecherchen wurden vom Essener Forschungsinstitut für Medizinmanagement $\mathrm{GmbH}$ (EsFoMed) durchgeführt. Teilweise wurde auf die Evidenzbewertung der NICE-Guideline Menopause und S3-Leitlinien der AWMF im Sinne einer Leitlinienadaptation zurückgegriffen.

Empfehlungen Es werden Empfehlungen zu folgenden Themen gegeben: Diagnostik und therapeutische Interventionen bei peri- und postmenopausalen Frauen, Urogynäkologie, kardiovaskuläre Erkrankungen, Osteoporose, Demenz, Depression, Stimmungsschwankungen, Hormontherapie und Krebsrisiko sowie prämature Ovarialinsuffizienz. 


\section{Guideline Information}

\section{Guidelines program of the DGGG, OEGGG and SGGG}

For information on the guidelines program, please refer to the end of this guideline.

\section{Citation format}

Perimenopause and Postmenopause - Diagnosis and Interventions. Guideline of the DGGG and OEGGG (S3-Level, AWMF Registry Number 015-062, September 2020). Geburtsh Frauenheilk 2021; 81: 612-636

\section{Guideline documents}

The complete long version of this guideline and the guideline report, which includes a list of the conflicts of interest of all of the authors, are available in German on the homepage of the AWMF: http://www.awmf.org/leitlinien/detail/II/015-062.html

\section{Guideline authors}

\section{See $>$ Tables 1 to 4 .}

- Table 1 Lead author and coordinating guideline author.

\begin{tabular}{|l|l|}
\hline Author & AWMF professional society \\
\hline Prof. Dr. Olaf Ortmann & DGGG \\
\hline
\end{tabular}

The professional societies/working groups/organizations/associations listed below have stated their interest in being involved in preparing the text of the guideline and participating in the consensus conference and appointed representatives to attend the consensus conference:

- Table 2 Who are the guideline authors representing? Contributing target user groups.

\section{DGGG working group/AWMF/non-AWMF professional society/ organization/association}

Gynecological Oncology Working Group

[Arbeitsgemeinschaft Gynäkologische Onkologie] (AGO)

Urogynecology and Pelvic Floor Reconstruction Study Group

[Arbeitsgemeinschaft für Urogynäkologie und plastische Becken-

bodenrekonstruktion] (AGUB)

Professional Association of Gynecologists

[Berufsverband der Frauenärzte] (BVF)

German, Austrian and Swiss Society for the Prevention of Cardiovascular Disease [D.A.CH-Gesellschaft Prävention von Herz-Kreislauf-Erkrankungen e.V.]

German Society for General and Family Medicine [Deutsche Gesellschaft für Allgemeinmedizin und Familienmedizin] (DEGAM)

German Society for Angiology/Vascular Medicine [Deutsche Gesellschaft für Angiologie, Gesellschaft für Gefäßmedizin] (DGA)

German Society of Endocrinology

[Deutsche Gesellschaft für Endokrinologie] (DGE)
- Table 2 Who are the guideline authors representing? Contributing target user groups. (Continued)

\section{DGGG working group/AWMF/non-AWMF professional society/} organization/association

German Society for Gynecological Endocrinology and Reproductive Medicine [Deutsche Gesellschaft für Gynäkologie, Endokrinologie und Fortpflanzungsmedizin] (DGGEF)

German Society of Gynecology and Obstetrics

[Deutsche Gesellschaft für Gynäkologie und Geburtshilfe] (DGGG)

German Society for Hematology and Medical Oncology [Deutsche Gesellschaft für Hämatologie und Medizinische Onkologie] (DGHO)

German Society for Internal Medicine

[Deutsche Gesellschaft für Innere Medizin] (DGIM)

German Society for Cardiology, Heart and Circulation [Deutsche Gesellschaft für Kardiologie - Herz- und Kreislaufforschung] (DGK)

German Society of Neurology [Deutsche Gesellschaft für Neurologie] (DGN)

German Society of Pharmacology [Deutsche Gesellschaft für Pharmakologie] (DGP)

German Society for Psychosomatic Gynecology and Obstetrics [Deutsche Gesellschaft für psychosomatische Frauenheilkunde und Geburtshilfe] (DGPFG)

German Society for Psychiatry and Psychotherapy, Psychosomatics and Neurology [Deutsche Gesellschaft für Psychiatrie und Psychotherapie, Psychosomatik und Nervenheilkunde] (DGPPN)

German Society for Senology [Deutsche Gesellschaft für Senologie] (DGS)

German Cancer Society [Deutsche Krebsgesellschaft] (DKG)

German Menopause Society [Deutsche Menopause Gesellschaft] (DMG)

German Osteology Association [Dachverband Osteologie] (DVO)

European Menopause and Andropause Society (EMAS)

Women's Self-Help After Cancer Organization [Frauenselbsthilfe nach Krebs]

Society for Phytotherapy [Gesellschaft für Phytotherapie] (GPT)

International Menopause Society (IMS)

Austrian Society of Gynecology and Obstetrics [Österreichische Gesellschaft für Gynäkologie und Geburtshilfe] (OEGGG)

Swiss Society of Gynecology and Obstetrics [Schweizerische Gesellschaft für Gynäkologie und Geburtshilfe] (SGGG)

The SGGG has published two Expert Letters on the topic, which the respective specialists have declared to be still authoritative for Switzerland (the German- and French-speaking areas of Switzerland). For this reason and based on the advice of the AGER, the executive board of the SGGG has decided not to adopt the S3 guideline "Perimenopause and Postmenopause".

This guideline was moderated by Dr. med. Monika Nothacker (AWMF-certified guideline moderator).

- Table 3 Who are the guideline authors representing? Contributing target patient groups.

\section{AWMF/non-AWMF professional society/organization/association}

Women's Self-Help After Cancer [Frauenselbsthilfe nach Krebs e. V.] 
- Table 4 Guideline authors (in alphabetical order).

\begin{tabular}{|c|c|}
\hline $\begin{array}{l}\text { Author } \\
\text { Mandate holder }\end{array}$ & $\begin{array}{l}\text { DGGG working group (AG)/ } \\
\text { AWMF/non-AWMF professional } \\
\text { society/organization/association }\end{array}$ \\
\hline Dr. med. C. Albring & BVF, member of the Steering Committee \\
\hline Prof. Dr. E. Baum & DEGAM \\
\hline Dr. med. M. Beckermann & DGPFG \\
\hline Prof. Dr. K. Bühling & D.A.CH \\
\hline Prof. Dr. G. Emons & DGGG \\
\hline Prof. Dr. T. Gudermann & DGP \\
\hline Prof. Dr. P. Hadji & DVO \\
\hline Prof. Dr. B. Imthurn & SGGG \\
\hline PD Dr. med. E. C. Inwald & 2nd coordinating guideline author \\
\hline Prof. Dr. L. Kiesel & $\begin{array}{l}\text { DMG, member of the Steering } \\
\text { Committee }\end{array}$ \\
\hline Prof. Dr. D. Klemperer & Expert, patient information \\
\hline Dr. P. Klose & $\begin{array}{l}\text { Mandate holder representing } \\
\text { Prof. Langhorst, GPT }\end{array}$ \\
\hline Dr. med. K. König & BVF \\
\hline Prof. Dr. S. Krüger & DGPPN \\
\hline Prof. Dr. J. Langhorst & GPT \\
\hline Prof. Dr. M. Leitzmann & Expert, epidemiology \\
\hline Prof. Dr. A. Ludolph & DGN \\
\hline Prof. Dr. D. Lüftner & DGHO \\
\hline Ms. D. Müller & Women's Self-Help After Cancer \\
\hline Prof. Dr. J. Neulen & DGGEF \\
\hline Dr. med. M. Nothacker & AWMF \\
\hline Prof. Dr. O. Ortmann & $\begin{array}{l}\text { Coordinating guideline author, } \\
\text { lead author, member of the Steering } \\
\text { Committee }\end{array}$ \\
\hline $\begin{array}{l}\text { Prof. Dr. E. Petri } \\
\text { (died } 21 \text { September 2019) }\end{array}$ & AGUB \\
\hline Dr. med. H. Prautzsch & DEGAM \\
\hline Prof. Dr. F. Regitz-Zagrosek & DGK \\
\hline Dr. med. K. Schaudig & Expert, gynecological endocrinology \\
\hline Prof. Dr. F. Schütz & DGS \\
\hline Dr. med. A. Schwenkhagen & Expert, gynecological endocrinology \\
\hline Prof. Dr. T. Strowitzki & DGE \\
\hline Prof. Dr. P. Stute & $\begin{array}{l}\text { EMAS, member of the Steering } \\
\text { Committee }\end{array}$ \\
\hline Prof. Dr. B.-M. Taute & DGA \\
\hline Prof. Dr. C. Tempfer & AGO \\
\hline Prof. Dr. C. von Arnim & DGN \\
\hline Prof. Dr. L. Wildt & OEGGG \\
\hline Prof. Dr. E. Windler & $\begin{array}{l}\text { DGIM, member of the Steering } \\
\text { Committee }\end{array}$ \\
\hline
\end{tabular}

\section{Purpose and objectives}

The guideline authors compiled consensual recommendations and statements on issues in the following areas:

- diagnosis and therapeutic interventions for perimenopausal and postmenopausal women

- urogynecology

- cardiovascular disease

- osteoporosis

- dementia, depression, mood swings

- HRT and cancer risk

- primary ovarian insufficiency (POI)

- other diseases

\section{Targeted areas of patient care}

- Inpatient care

- Outpatient care

\section{Target user groups/target audience}

The guideline is aimed at physicians who advise perimenopausal and postmenopausal women about the physiological changes, disorders and treatment options and treat them, for example:

- gynecologists in private practice

- hospital-based gynecologists

- physicians who advise perimenopausal and postmenopausal women and treat their symptoms and disorders, e.g., general practitioners, specialists for internal medicine, psychiatrists, neurologists, etc.

\section{Adoption and period of validity}

The validity of this guideline was confirmed by the executive boards/heads of the participating medical professional societies, working groups, organizations and associations as well as by the boards of the DGGG, the DGGG guidelines commission, and the OEGGG in October and November of 2018 and was thus approved in its entirety. The guideline was published in January 2020 and was updated in September 2020 by the addition of an addendum. This guideline is valid from 1st January 2020 through to 31st December 2024. Because of the contents of this guideline, this period of validity is only an estimate.

Should changes become necessary before the guideline's period of validity has expired, the Steering Committee will consult together on the issues and vote on proposed changes together with the guideline authors, using a structured consensus process.

\section{Methodology}

\section{Basic principles}

The method used to prepare this guideline was determined by the class to which this guideline was assigned. The AWMF Guidance Manual (version 1.0) has set out the respective rules and requirements for different classes of guidelines. Guidelines are differentiated into lowest (S1), intermediate (S2), and highest (S3) class. The lowest class is defined as consisting of a set of recommenda- 
tions for action compiled by a non-representative group of experts. In 2004, the S2 class was divided into two subclasses: a systematic evidence-based subclass (S2e) and a structural consensus-based subclass ( $\mathrm{S} 2 \mathrm{k}$ ). The highest $\mathrm{S3}$ class combines both approaches.

This guideline has been classified as: S3

\section{Grading of evidence}

To evaluate the evidence (levels 1-5), this guideline uses the classification system of the Oxford Centre for Evidence-based Medicine in its most current version dating from 2009 ( $\bullet$ Table 5).

- Table 5 Grading of evidence based on the Oxford classification system (from March 2009).

\begin{tabular}{|c|c|c|c|c|c|}
\hline Level & $\begin{array}{l}\text { Therapy/prevention, } \\
\text { etiology/harm }\end{array}$ & Prognosis & Diagnosis & $\begin{array}{l}\text { Differential } \\
\text { diagnosis/symptom } \\
\text { prevalence study }\end{array}$ & $\begin{array}{l}\text { Economic and } \\
\text { decision analyses }\end{array}$ \\
\hline $1 \mathrm{a}$ & $\begin{array}{l}\text { SYSTEMATIC REVIEWS } \\
\text { (with homogeneity*) } \\
\text { of RANDOMIZED CON- } \\
\text { TROLLED TRIALSs }\end{array}$ & $\begin{array}{l}\text { SYSTEMATIC REVIEWS } \\
\text { (with homogeneity*) } \\
\text { of inception cohort } \\
\text { studies; CLINICAL } \\
\text { DECISION RULE" } \\
\text { validated in different } \\
\text { populations }\end{array}$ & $\begin{array}{l}\text { SYSTEMATIC REVIEWS } \\
\text { (with homogeneity*) }^{*} \\
\text { of Level } 1 \text { diagnostic } \\
\text { studies; CLINICAL } \\
\text { DECISION RULE" with } \\
\text { 1b studies from differ- } \\
\text { ent clinical centers }\end{array}$ & $\begin{array}{l}\text { SYSTEMATIC REVIEWS } \\
\text { (with homogeneity*) } \\
\text { of prospective cohort } \\
\text { studies }\end{array}$ & $\begin{array}{l}\text { SYSTEMATIC REVIEWS } \\
\text { (with homogeneity*) }^{*} \\
\text { of Level } 1 \text { economic } \\
\text { studies }\end{array}$ \\
\hline $1 b$ & $\begin{array}{l}\text { Individual RANDOM- } \\
\text { IZED CONTROLLED } \\
\text { TRIALS (with narrow } \\
\text { confidence interval"i) }\end{array}$ & $\begin{array}{l}\text { Individual inception } \\
\text { cohort study with } \\
>80 \% \text { follow-up; } \\
\text { CLINICAL DECISION } \\
\text { RULE" validated in } \\
\text { a single population }\end{array}$ & $\begin{array}{l}\text { Validating** cohort } \\
\text { study with good" " " } \\
\text { reference standards; } \\
\text { or CLINICAL DECISION } \\
\text { RULE" tested within } \\
\text { one clinical center }\end{array}$ & $\begin{array}{l}\text { Prospective cohort } \\
\text { study with good } \\
\text { follow-up**** }\end{array}$ & $\begin{array}{l}\text { Analysis based on } \\
\text { clinically sensible } \\
\text { costs or alternatives; } \\
\text { systematic review(s) of } \\
\text { the evidence; and } \\
\text { including multi-way } \\
\text { sensitivity analyses }\end{array}$ \\
\hline $1 c$ & All-or-none ${ }^{\S}$ & All-or-none case series & $\begin{array}{l}\text { Absolute SPins and } \\
\text { SNouts" " }\end{array}$ & All-or-none case series & $\begin{array}{l}\text { Absolute better- } \\
\text { value or worse-value } \\
\text { analyses" " " " }\end{array}$ \\
\hline $2 a$ & $\begin{array}{l}\text { SYSTEMATIC REVIEWS } \\
\text { (with homogeneity*) }^{*} \\
\text { of cohort studies }\end{array}$ & $\begin{array}{l}\text { SYSTEMATIC REVIEWS } \\
\text { (with homogeneity*) } \\
\text { of either retrospective } \\
\text { cohort studies or un- } \\
\text { treated control groups } \\
\text { in RANDOMIZED CON- } \\
\text { TROLLED TRIALSs }\end{array}$ & $\begin{array}{l}\text { SYSTEMATIC REVIEWS } \\
\text { (with homogeneity*) }^{*} \\
\text { of level > } 2 \text { diagnostic } \\
\text { studies }\end{array}$ & $\begin{array}{l}\text { SYSTEMATIC REVIEWS } \\
\text { (with homogeneity*) } \\
\text { of } 2 \text { b and better studies }\end{array}$ & $\begin{array}{l}\text { SYSTEMATIC REVIEWS } \\
\text { (with homogeneity*) }^{*} \\
\text { of level > } 2 \text { economic } \\
\text { studies }\end{array}$ \\
\hline $2 b$ & $\begin{array}{l}\text { Individual cohort study } \\
\text { (including low quality } \\
\text { RANDOMIZED CON- } \\
\text { TROLLED TRIALS; } \\
\text { e.g., < } 80 \% \text { follow-up) }\end{array}$ & $\begin{array}{l}\text { Retrospective cohort } \\
\text { study or follow-up of } \\
\text { untreated control pa- } \\
\text { tients in RANDOMIZED } \\
\text { CONTROLLED TRIALS; } \\
\text { Derivation of CLINICAL } \\
\text { DECISION RULE" or } \\
\text { validated on split- } \\
\text { sample } \S^{\S \S} \text { only }\end{array}$ & $\begin{array}{l}\text { Exploratory** cohort } \\
\text { study with good" " " } \\
\text { reference standards; } \\
\text { CLINICAL DECISION } \\
\text { RULE" after derivation, } \\
\text { or validated only } \\
\text { on split-sample } \S^{\text {or }} \\
\text { databases }\end{array}$ & $\begin{array}{l}\text { Retrospective } \\
\text { cohort study, } \\
\text { or poor follow-up }\end{array}$ & $\begin{array}{l}\text { Analysis based on clini- } \\
\text { cally sensible costs or } \\
\text { alternatives; limited re- } \\
\text { view(s) of the evidence, } \\
\text { or single studies; and } \\
\text { including multi-way } \\
\text { sensitivity analyses }\end{array}$ \\
\hline 2c & $\begin{array}{l}\text { “Outcomes” Research; } \\
\text { Ecological studies }\end{array}$ & “Outcomes" Research & & Ecological studies & $\begin{array}{l}\text { Audit or outcomes } \\
\text { research }\end{array}$ \\
\hline $3 a$ & $\begin{array}{l}\text { SYSTEMATIC REVIEWS } \\
\text { (with homogeneity* }^{*} \text { ) } \\
\text { of case-control studies }\end{array}$ & & \multicolumn{3}{|c|}{ SYSTEMATIC REVIEWS (with homogeneity*) of $3 \mathrm{~b}$ and better studies } \\
\hline $3 b$ & $\begin{array}{l}\text { Individual case-control } \\
\text { study }\end{array}$ & & $\begin{array}{l}\text { Non-consecutive } \\
\text { study; or without } \\
\text { consistently applied } \\
\text { reference standards }\end{array}$ & $\begin{array}{l}\text { Non-consecutive } \\
\text { cohort study, or very } \\
\text { limited population }\end{array}$ & $\begin{array}{l}\text { Analysis based on } \\
\text { limited alternatives } \\
\text { or costs, poor quality } \\
\text { estimates of data, but } \\
\text { including sensitivity } \\
\text { analyses incorporating } \\
\text { clinically sensible } \\
\text { variations. }\end{array}$ \\
\hline
\end{tabular}


- Table 5 Grading of evidence based on the Oxford classification system (from March 2009). (Continued)

\begin{tabular}{|c|c|c|c|c|c|}
\hline Level & $\begin{array}{l}\text { Therapy/prevention, } \\
\text { etiology/harm }\end{array}$ & Prognosis & Diagnosis & $\begin{array}{l}\text { Differential } \\
\text { diagnosis/symptom } \\
\text { prevalence study }\end{array}$ & $\begin{array}{l}\text { Economic and } \\
\text { decision analyses }\end{array}$ \\
\hline 4 & $\begin{array}{l}\text { Case series (and poor- } \\
\text { quality cohort and } \\
\text { case-control studies }{ }^{\S} \text { ) }\end{array}$ & $\begin{array}{l}\text { Case series (and poor- } \\
\text { quality prognostic } \\
\text { cohort studies }{ }^{* *} \text { ) }\end{array}$ & $\begin{array}{l}\text { Case-control study, } \\
\text { poor or non-indepen- } \\
\text { dent reference } \\
\text { standard }\end{array}$ & $\begin{array}{l}\text { Case series or } \\
\text { superseded reference } \\
\text { standards }\end{array}$ & $\begin{array}{l}\text { Analysis with no } \\
\text { sensitivity analysis }\end{array}$ \\
\hline 5 & \multicolumn{4}{|c|}{ Expert opinion without explicit critical appraisal, or based on physiology, bench research or "first principles" } & $\begin{array}{l}\text { Expert opinion } \\
\text { without explicit critical } \\
\text { appraisal, or based on } \\
\text { economic theory or } \\
\text { "first principles" }\end{array}$ \\
\hline
\end{tabular}

Source (contents, abbreviations, notes): http://www.cebm.net/?o=1025

\section{Grading of recommendations}

While grading the quality of the evidence (strength of evidence) should be an indication of the resilience of published data and thus of the level of certainty/uncertainty associated with the data, the level of recommendation reflects the result of weighing up desired and unwanted consequences of alternative approaches.

The level of obligation indicates the medical importance of complying with a guideline recommendation when the recommendation is based on the current state of scientific knowledge. When this is not the case, it is possible or even imperative to deviate from the recommendation given this guideline. The body publishing this guideline is not creating legally binding obligations, because it has no legal powers to pass laws, directives, or ordinances (within the meaning of German laws on ordinances and directives). This approach has been confirmed by the German Federal High Court of Justice (Decision of the Federal High Court of Justice VI ZR 382/12).

Grading the evidence in S2e/S3-level guidelines using the Oxford classification permits gradations of recommendations to be made for this type of guideline. Symbols are used to indicate the level of obligation to comply with the recommendation, with the three different levels of obligation reflected by the different strengths of the linguistic terminology. This type of grading is currently generally used, not just by the AWMF but also by the German Medical Association and its National Healthcare Guidelines [Nationale Versorgungsleitlinien (NVL)] ( $\triangleright$ Table 6 ).

- Table 6 Grading of recommendations (in English, according to Lomotan et al. Qual Saf Health Care 2010).

\begin{tabular}{|l|l|l|}
\hline Symbols & Description of binding character & Expression \\
\hline A & $\begin{array}{l}\text { Strong recommendation with } \\
\text { highly binding character }\end{array}$ & must/must not \\
\hline B & $\begin{array}{l}\text { Regular recommendation with } \\
\text { moderately binding character }\end{array}$ & should/should not \\
\hline 0 & $\begin{array}{l}\text { Open recommendation with } \\
\text { limited binding character }\end{array}$ & may/may not \\
\hline
\end{tabular}

In addition to evaluating the evidence, the above listed classification of recommendations also reflects the clinical relevance of underlying studies and measures/factors which were not included in the grading of the evidence, such as the choice of patient population, intention-to-treat or per-protocol-outcome analyses, medical or ethical behavior toward the patient, country-specific applicability, etc. Thus, there may be linear correlation between a strong, moderate or weak level of evidence leading to a strong, ordinary or open recommendation. Upgrading to a Grade A recommendation or downgrading to a Grade 0 recommendation is only possible for moderate levels of evidence. In exceptional circumstances, additional background information will have to be provided if the highest level of evidence only leads to a weak/open recommendation or vice versa.

- Strong level of evidence

$\rightarrow$ Grade A or Grade B recommendation

- Moderate level of evidence

$\rightarrow$ Grade A or Grade B or Grade 0 recommendation

- Weak level of evidence

$\rightarrow$ Grade B or Grade 0 recommendation

\section{Statements}

Expositions or explanations of specific facts, circumstances or problems without any direct recommendations for action included in this guideline are referred to as "Statements". It is not possible to provide any information about the grading of evidence for these Statements.

\section{Achieving consensus and level of consensus}

At structured consensus-based conferences (S2k/S3 level), authorized participants attending the session vote on draft statements and recommendations. This may lead to significant amendments to formulations, etc. Finally, the extent of consensus is determined based on the number of participants. ( $\vee$ Table 7 ). 
- Table 7 Classification of strength of consensus.

\begin{tabular}{|l|l|l|}
\hline Symbol & Level of consensus & Extent of agreement in percent \\
\hline+++ & Strong consensus & $>95 \%$ participants agree \\
\hline++ & Consensus & $>75-95 \%$ participants agree \\
\hline+ & Majority agreement & $>50-75 \%$ participants agree \\
\hline- & No consensus & $<51 \%$ participants agree \\
\hline
\end{tabular}

\section{Expert consensus}

As the name already implies, this refers to consensus decisions taken specifically with regard to recommendations/statements made without a prior systematic search of the literature (S2k) or for which evidence is lacking (S2e/S3). The term "expert consensus" (EC) used here is synonymous with terminology used in other guidelines such as "good clinical practice" (GCP) or "clinical consensus point" (CCP). The strength of the recommendation is graded as previously described in the chapter on the grading of recommendations but without the use of symbols; it is only expressed semantically ("must"|“must not" or "should"|"should not" or "may"|"may not").

\section{Guideline}

\section{Diagnosis and therapeutic interventions in perimenopausal and postmenopausal women}

Diagnosis

\begin{tabular}{|c|c|c|}
\hline \multicolumn{3}{|c|}{ Evidence-based recommendation 1.E1 } \\
\hline $\begin{array}{l}\text { Level of evidence } \\
\text { LLA }\end{array}$ & $\begin{array}{l}\text { Level of recom- } \\
\text { mendation A }\end{array}$ & $\begin{array}{l}\text { Level of consensus } \\
++\end{array}$ \\
\hline
\end{tabular}

A diagnosis of perimenopause and postmenopause in women over the age of 45 must be based on clinical parameters.

\begin{tabular}{|c|c|c|}
\hline \multicolumn{3}{|c|}{ Evidence-based recommendation 1.E2 } \\
\hline $\begin{array}{l}\text { Level of evidence } \\
\text { LLA }\end{array}$ & $\begin{array}{l}\text { Level of recom- } \\
\text { mendation } A\end{array}$ & $\begin{array}{l}\text { Level of consensus } \\
++\end{array}$ \\
\hline \multicolumn{3}{|c|}{$\begin{array}{l}\text { Using FSH levels to diagnose perimenopause and postmenopause must } \\
\text { only be done in women between the ages of } 40 \text { and } 45 \text { years with } \\
\text { menopausal symptoms (e.g., hot flushes, changes in their menopausal } \\
\text { cycle) and in women below the age of } 40 \text { if there are indications of } \\
\text { primary ovarian insufficiency. }\end{array}$} \\
\hline
\end{tabular}

\section{Therapeutic interventions}

\begin{tabular}{|c|c|c|}
\hline \multicolumn{3}{|c|}{ Evidence-based recommendation $1 . \mathrm{E} 3$} \\
\hline $\begin{array}{l}\text { Level of evidence } \\
\text { 1a }\end{array}$ & $\begin{array}{l}\text { Level of recom- } \\
\text { mendation } A\end{array}$ & $\begin{array}{l}\text { Level of consensus } \\
++\end{array}$ \\
\hline \multicolumn{3}{|c|}{$\begin{array}{l}\text { Women with vasomotor symptoms must be offered HRT after they } \\
\text { have been informed about the short-term (up to } 5 \text { years) and long-term } \\
\text { benefits and risks of treatment. EPT with an appropriate progestogen } \\
\text { dose should be considered for non-hysterectomized women while } \\
\text { hysterectomized Frauen should receive ET. }\end{array}$} \\
\hline
\end{tabular}

Before starting hormone treatment, women should be informed that the vasomotor symptoms may return again when they terminate HRT.

\begin{tabular}{|c|c|c|}
\hline \multicolumn{3}{|c|}{ Evidence-based recommendation 1.E4 } \\
\hline $\begin{array}{l}\text { Level of evidence } \\
3\end{array}$ & $\begin{array}{l}\text { Level of recom- } \\
\text { mendation } A\end{array}$ & $\begin{array}{l}\text { Level of consensus } \\
++\end{array}$ \\
\hline \multicolumn{3}{|c|}{$\begin{array}{l}\text { Selective serotonin reuptake inhibitors (SSRIs), serotonin-nor- } \\
\text { epinephrine reuptake inhibitors (SNRIs), clonidine and gabapentin } \\
\text { must not be routinely prescribed as first-choice drugs for vasomotor } \\
\text { symptoms. }\end{array}$} \\
\hline
\end{tabular}

\begin{tabular}{|c|c|c|}
\hline \multicolumn{3}{|c|}{ Evidence-based recommendation 1.E5 } \\
\hline $\begin{array}{l}\text { Level of evidence } \\
\text { 1b }\end{array}$ & $\begin{array}{l}\text { Level of recom- } \\
\text { mendation } 0\end{array}$ & $\begin{array}{l}\text { Level of consensus } \\
++\end{array}$ \\
\hline
\end{tabular}

For the dissenting opinion of the Society for Phytotherapy, see the "Vote of the Society for Phytotherapy (GPT)" in the long version of this guideline.

Efficacy and safety of interventions

> Tables 8 and 9. 
- Table 8 Efficacy and risks of different interventions for hot flushes.

\begin{tabular}{|c|c|c|c|}
\hline & Verified benefit & Possible benefit & Unlikely to be beneficial \\
\hline $\begin{array}{l}\text { Low risk of harm or of } \\
\text { discontinuing treatment }\end{array}$ & $\begin{array}{l}\text { Expectant management or } \\
\text { placebo, CBT (mindfulness, } \\
\text { cognitive und behavioral } \\
\text { therapy) }\end{array}$ & $\begin{array}{l}\text { Black cohosh 5-6.5 mg/d (herbal prepara- } \\
\text { tion), isoflavones 30-80 mg/d, incl. phyto- } \\
\text { estrogen-rich diet, red clover, S-equol, } \\
\text { genistein 30-60 mg/d, rheum rhaponticum, } \\
\text { acupuncture, St. John's wort } 300 \mathrm{mg} / \mathrm{d}\end{array}$ & $\begin{array}{l}\text { Sports ( } 3-6 \text { months), deep } \\
\text { relaxation ( } 4-12 \text { weeks), } \\
\text { vitamin } \mathrm{E}\end{array}$ \\
\hline $\begin{array}{l}\text { Moderate risk of harm or of } \\
\text { discontinuing treatment }\end{array}$ & estrogens, tibolone & SSRI, SNRI, gabapentin, clonidine & $\begin{array}{l}\text { DHEA } \\
\text { (dehydroepiandrosterone) } \\
\text { Raloxifene }\end{array}$ \\
\hline $\begin{array}{l}\text { Risk of harm not sufficiently } \\
\text { investigated }\end{array}$ & & & $\begin{array}{l}\text { Chinese herbal remedies used } \\
\text { in TCM, melatonin }\end{array}$ \\
\hline
\end{tabular}

- Table 9 Efficacy (= reduced frequency of hot flushes) of different interventions and probability that the patient will discontinue treatment compared to placebo in non-hysterectomized women who present with vasomotor perimenopausal and postmenopausal symptoms.

\begin{tabular}{|l|l|l|}
\hline Intervention & $\begin{array}{l}\text { MR (mean ratio) } \\
\text { Efficacy }\end{array}$ & $\begin{array}{l}\text { OR (odds ratio) } \\
\text { Treatment discontinued* }\end{array}$ \\
\hline Non-oral estrogen plus progestogens & $0.23(0.09-0.7)$ & \\
\hline Black cohosh & $0.4(0.17-0.9)$ & $0.61(0.73-0.99)$ \\
\hline Oral estrogen plus progestogens & $0.52(0.25-1.06)$ & $5.65(0.94-172.9)$ \\
\hline Tibolone & $0.55(0.24-1.29)$ & $0.95(0.51-1.76)$ \\
\hline Acupuncture & $0.58(0.23-1.36)$ & $0.5(0.07-4.3)$ \\
\hline Isoflavones & $0.62(0.44-0.87)$ & $1.66(1.07-2.61)$ \\
\hline Herbal remedies & $0.71(0.24-2.07)$ & $1.58(0.42-6.66)$ \\
\hline Sham acupuncture & $0.75(0.19-1.9)$ & \\
\hline SSRI/SNRIs & $0.84(0.54-1.31)$ & $0.31(0.1-1.0)$ \\
\hline Chinese herbal remedies & $0.95(0.46-1.9)$ & $0.88(0.63-1.23)$ \\
\hline Raloxifene & $1.65(0.61-4.51)$ & $0.4(0.01-5.4)$ \\
\hline CEE + bazedoxifene & & \\
\hline Gabapentin & & \\
\hline Valerian root & & \\
\hline${ }^{*}$ An OR of less than 1 signifies treatment compliance; an OR of more than 1 indicates the risk of treatment being discontinued.
\end{tabular}

\section{Changes in sexual functioning}

\section{Evidence-based recommendation 1.E6

\begin{tabular}{l|l|l|l|l|l|l|l}
$\begin{array}{l}\text { Level of evidence } \\
\text { 1b }\end{array}$ & $\begin{array}{l}\text { Level of recom- } \\
\text { mendation } 0\end{array}$ & $\begin{array}{l}\text { Level of consensus } \\
++\end{array}$ \\
\hline
\end{tabular}

Testosterone therapy may be considered after psychosexual exploration for women who experience a loss of libido in perimenopause and postmenopause if HRT is not effective. The patient must be informed that this is an off-label use.

Urogenital atrophy

\section{Evidence-based recommendation 1.E7

\begin{tabular}{|l|l|l|}
$\begin{array}{l}\text { Level of evidence } \\
\text { 1b }\end{array}$ & $\begin{array}{l}\text { Level of recom- } \\
\text { mendation A }\end{array}$ & $\begin{array}{l}\text { Level of consensus } \\
+++\end{array}$ \\
\hline
\end{tabular}

Women with symptomatic urogenital atrophy must be offered the use of moisturizers and lubricants either as a stand-alone treatment or together with vaginal ET. Treatment may be continued for as long as necessary.

Estriol-based preparations should be preferred for vaginal estrogen applications. Routine vaginal sonography to measure endometrial thickness must not be carried out when the patient is being treated with topical ET (cf. S3-guideline Endometrial Cancer, AWMF registry number 032-034). 


\section{Urogynecology}

\section{Stress incontinence}

\section{Evidence-based statement 2.51}

Level of evidence $1 \mathrm{a}$

Level of consensus ++

Vaginal ET may improve urinary incontinence in postmenopausal women.

\section{Evidence-based recommendation 2.E8 \\ \begin{tabular}{|l|l|l|l}
\hline Level of evidence & Level of recom- & Level of consensus \\
\hline
\end{tabular} $1 a$ mendation A}

\section{Evidence-based recommendation 2.E10}

\section{Level of evidence Level of recom-}

$1 \mathrm{~b}$

mendation 0

Level of consensus

$++$

Once urological disease has been ruled out as the cause of urge symptoms, the patient may be offered topical ET. This may reduce the frequency of urination and urge symptoms.

\section{Recurrent urinary tract infections}

\section{Evidence-based statement 2.53}

Level of evidence 2

\section{Level of consensus ++}

Changes to the vaginal $\mathrm{pH}$ and microbiome in postmenopausal women predispose them to urinary tract infections. There is a positive correlation with older age.

treatment may lead to urinary incontinence or result in a worsening of urinary incontinence.

\section{Evidence-based recommendation 2.E9 \\ Level of evidence Level of recom- \\ 1 a mendation A \\ Level of consensus$$
++
$$

Postmenopausal patients with urinary incontinence must be offered pelvic floor training and vaginal ET.

Overactive bladder

\section{Evidence-based statement 2.52}

\begin{tabular}{|l|l}
\hline Level of evidence 1b & Level of consensus +++
\end{tabular}

Systemic HRT may worsen existing urinary incontinence. Vaginal ET may be offered to women with overactive bladder (OAB).
$2 a$

When postmenopausal women have recurrent cystitis, vaginal ET should be carried out before starting long-term antibiotic prophylaxis.

\section{$3 \quad$ Cardiovascular disease}

\begin{tabular}{|c|c|c|}
\hline \multicolumn{3}{|c|}{ Evidence-based recommendation 3.E12 } \\
\hline $\begin{array}{l}\text { Level of evidence } \\
2 \mathrm{~b}\end{array}$ & $\begin{array}{l}\text { Level of recom- } \\
\text { mendation B }\end{array}$ & $\begin{array}{l}\text { Level of consensus } \\
++\end{array}$ \\
\hline
\end{tabular}

The basic cardiovascular risk of perimenopausal and postmenopausal women varies greatly, depending on the individual risk factors. Risk factors should be optimally controlled to ensure that they do not constitute a contraindication for HRT. Vascular risk factors should therefore be investigated and treated before starting HRT ( $\vee$ Table 10 ).

- Table 10 Effects of oral HRT on cardiovascular disease in the Women's Health Initiative.

\begin{tabular}{|c|c|c|c|c|c|c|c|c|c|c|}
\hline & \multicolumn{5}{|l|}{ EPT } & \multicolumn{5}{|l|}{ ET } \\
\hline & Verum & Control & HR & $95 \% \mathrm{Cl}$ & $\mathbf{p}$ & Verum & Control & HR & $95 \% \mathrm{Cl}$ & $\mathbf{p}$ \\
\hline $\begin{array}{l}\text { Deep vein } \\
\text { thrombosis }\end{array}$ & 122 & 61 & 1.87 & $1.37,2.54$ & $<0.001$ & 85 & 59 & 1.48 & $1.06,2.07$ & 0.02 \\
\hline Stroke & 159 & 109 & 1.37 & $1.07,1.76$ & 0.01 & 169 & 130 & 1.35 & $1.07,1.70$ & 0.01 \\
\hline $\begin{array}{l}\text { Coronary } \\
\text { heart disease }\end{array}$ & 196 & 159 & 1.18 & $0.95,1.45$ & 0.13 & 204 & 222 & 0.94 & $0.78,1.14$ & 0.53 \\
\hline $\begin{array}{l}\text { Cardiovascular } \\
\text { mortality }\end{array}$ & 79 & 70 & 1.05 & $0.76,1.45$ & 0.77 & 109 & 112 & 1.00 & $0.77,1.31$ & 0.98 \\
\hline Overall mortality & 250 & 238 & 0.97 & $0.81,1.16$ & 0.76 & 301 & 299 & 1.03 & $0.88,1.21$ & 0.68 \\
\hline
\end{tabular}




\section{Thromboembolism}

Evidence-based recommendation 3.E13
\begin{tabular}{l|l|l} 
Level of evidence & $\begin{array}{l}\text { Level of recom- } \\
\text { mendation A }\end{array}$ & $\begin{array}{l}\text { Level of consensus } \\
++\end{array}$ \\
\hline $2 a$ &
\end{tabular}

Women must be informed that their risk of thromboembolism will be higher if they take oral ET or EPT and that the risk of thromboembolism associated with oral estrogen intake is higher than for transdermal applications.

\section{Cerebrovascular events}

\begin{tabular}{|c|c|c|}
\hline $\begin{array}{l}\text { Level of evidence } \\
2 \mathbf{b}\end{array}$ & $\begin{array}{l}\text { Level of recom- } \\
\text { mendation A }\end{array}$ & $\begin{array}{l}\text { Level of consensus } \\
++\end{array}$ \\
\hline
\end{tabular}

Women must be informed that oral EPT might increase the risk of ischemic cerebrovascular events but that transdermal ET does not. The absolute risk of stroke in younger women is very low.

\section{Coronary heart disease}

\begin{tabular}{l|l|l|}
\multicolumn{2}{|l|}{ Evidence-based recommendation 3.E15 } \\
\begin{tabular}{l|l|l} 
Level of evidence & Level of recom- & Level of consensus \\
mendation A & ++
\end{tabular} \\
\hline
\end{tabular}

Women must be informed that EPT does not increase cardiovascular risk or only minimally increases the risk and that ET neither increases nor decreases cardiovascular risk. When this evidence is considered alongside the risk of thromboembolism and ischemic stroke, it is clear that HRT is not suitable for the prevention of coronary heart disease but should be used to treat menopausal symptoms before the age of 60 .

\section{4}

\section{Osteoporosis}

\section{Evidence-based statement 4.54}

Level of evidence $1 \mathrm{a}$

Level of consensus +++

HRT significantly reduces the risk of osteoporosis-associated fractures.

\section{Evidence-based statement 4.55}

\begin{tabular}{|l|l|}
\hline Level of evidence $2 a$ & Level of consensus ++
\end{tabular}

The fracture-reducing effect of HRT was detectable irrespective of the duration of hormone intake (i.e., already after a short intake period of $<1$ year) or age at the start of therapy. Moreover, the fracture-reducing effect appears to persist to a lesser degree after terminating HRT $(\triangleright$ Tables 11 and 12$)$.
Table 11 Risk factors for osteoporosis.

\begin{tabular}{|c|c|}
\hline $\begin{array}{l}\text { Medical } \\
\text { specialty }\end{array}$ & Risk factor \\
\hline $\begin{array}{l}\text { General risk } \\
\text { factors/General } \\
\text { medicine }\end{array}$ & $\begin{array}{l}\text { - Age }(2 \times \text { to } 4 \times \text { higher per decade from } \\
\text { the age of } 50) \\
\text { - Gender (women/men: } 2 \text { to } 1) \\
\text { - Prevalence of vertebral body fractures } \\
(2 \times \text { to } 10 \times \text { higher) } \\
\text { - Low-trauma peripheral fracture } \\
\text { - Paternal or maternal proximal femur fracture } \\
\text { - Multiple falls } \\
\text { - Immobility } \\
\text { - Smoking } \\
\text { - Underweight }(B M I<20) \\
\text { - Cortisone therapy }>3 \text { months }>2.5 \mathrm{mg}\end{array}$ \\
\hline Endocrinology & $\begin{array}{l}\text { - Cushing's syndrome } \\
\text { - Primary hyperparathyroidism } \\
\text { - Growth hormone deficiency due to pituitary } \\
\text { insufficiency } \\
\text { - Hyperthyroidism } \\
\text { - Type } 1 \text { or type } 2 \text { diabetes mellitus } \\
\text { - Glitazone therapy }\end{array}$ \\
\hline Gastroenterology & $\begin{array}{l}\text { - B II gastric resection or gastrectomy } \\
\text { - Celiac disease } \\
\text { - Proton pump inhibitors }\end{array}$ \\
\hline $\begin{array}{l}\text { Geriatric } \\
\text { medicine }\end{array}$ & $\begin{array}{l}\text { - Sedatives } \\
\text { - Antipsychotics } \\
\text { - Benzodiazepines }\end{array}$ \\
\hline Gynecology & $\begin{array}{l}\text { - Aromatase inhibitors } \\
\text { - Hypogonadism }\end{array}$ \\
\hline Cardiology & - Congestive heart failure \\
\hline Neurology & $\begin{array}{l}\text { - Epilepsy and anti-epileptic drugs } \\
\text { - Depression and antidepressants }\end{array}$ \\
\hline Pneumology & - COPD \\
\hline $\begin{array}{l}\text { Rheumatology/ } \\
\text { Orthopedics }\end{array}$ & $\begin{array}{l}\text { - Rheumatoid arthritis } \\
\text { - Ankylosing spondylitis }\end{array}$ \\
\hline
\end{tabular}

- Table 12 Current treatment options for osteoporosis in postmenopausal women.

\begin{tabular}{|l|l|l|l|}
\hline $\begin{array}{l}\text { Antiresorptive } \\
\text { medication }\end{array}$ & $\begin{array}{l}\text { Evidence of } \\
\text { fewer verte- } \\
\text { bral body } \\
\text { fractures }\end{array}$ & $\begin{array}{l}\text { Fewer } \\
\text { peripheral } \\
\text { fractures }\end{array}$ & $\begin{array}{l}\text { Fewer } \\
\text { proximal } \\
\text { femur } \\
\text { fractures }\end{array}$ \\
\hline Aledronate & $\mathrm{A}$ & $\mathrm{A}$ & $\mathrm{A}$ \\
\hline Ibadronate & $\mathrm{A}$ & $\mathrm{B}$ & - \\
\hline Risedronate & $\mathrm{A}$ & $\mathrm{A}$ & $\mathrm{A}$ \\
\hline Zoledronic acid & $\mathrm{A}$ & $\mathrm{A}$ & $\mathrm{A}$ \\
\hline Denosumab & $\mathrm{A}$ & $\mathrm{A}$ & $\mathrm{A}$ \\
\hline Bazedoxifene & $\mathrm{A}$ & $\mathrm{B}$ & - \\
\hline Raloxifene & $\mathrm{A}$ & $\mathrm{B}$ & - \\
\hline Estrogens & $\mathrm{A}$ & $\mathrm{A}$ & $\mathrm{A}$ \\
\hline
\end{tabular}




\section{Dementia, depression, mood swings}

Evidence-based recommendation 5.E16
\begin{tabular}{|l|l|l|}
\hline $\begin{array}{l}\text { Level of evidence } \\
\text { LLA }\end{array}$ & $\begin{array}{l}\text { Level of recom- } \\
\text { mendation A }\end{array}$ & $\begin{array}{l}\text { Level of consensus } \\
+++\end{array}$ \\
\hline
\end{tabular}

Perimenopausal and postmenopausal women must be advised that it is not clear whether having HRT prior to the 65th year of life affects the risk of dementia.

\begin{tabular}{|c|c|c|}
\hline \multicolumn{3}{|c|}{ Evidence-based recommendation 5.E17 } \\
\hline $\begin{array}{l}\text { Level of evidence } \\
\text { LLA }\end{array}$ & $\begin{array}{l}\text { Level of recom- } \\
\text { mendation A }\end{array}$ & $\begin{array}{l}\text { Level of consensus } \\
++\end{array}$ \\
\hline
\end{tabular}

The indications for a pharmacological treatment of depression during perimenopause must comply with general treatment guidelines (there are no direct specific studies on its efficacy in perimenopause). There are currently no clear indications that there are any differences in the effectiveness of antidepressants based on menopausal status. There is insufficient evidence to recommend HRT or psychotherapy to treat perimenopausal depression.

\section{$6 \quad$ HRT and the risk of cancer}

HRT and the risk of breast cancer

\begin{tabular}{|c|c|c|}
\hline \multicolumn{3}{|c|}{ Evidence-based recommendation $6 . E 18$} \\
\hline $\begin{array}{l}\text { Level of evidence } \\
\text { 1a }\end{array}$ & $\begin{array}{l}\text { Level of recom- } \\
\text { mendation } A\end{array}$ & $\begin{array}{l}\text { Level of consensus } \\
++\end{array}$ \\
\hline
\end{tabular}

Women who are considering HRT must be informed that HRT (EPT/ET) may lead to a slight or even no increase in their risk of breast cancer. The potential increase in the level of risk depends on the composition of the specific HRT and the duration of HR intake and decreases after HRT is discontinued $(\triangleright$ Table 13$)$.

- Table 13 Absolute risk of breast cancer for different forms of HRT: differences in breast cancer incidence per 1000 postmenopausal women over a period of 7.5 years $(95 \% \mathrm{Cl})$.

\begin{tabular}{|l|l|l|}
\hline HRT type & Study type & Current use \\
\hline ET & RCT & 4 less $(-11$ to +8$)$ \\
\hline & Observational study & 6 more $(1$ to 12$)$ \\
\hline EPT & RCT & 5 more $(-4$ to 36$)$ \\
\hline & Observational study & 17 more (14 to 20$)$ \\
\hline
\end{tabular}

HRT after breast cancer

\section{Evidence-based statement 6.56}

Level of evidence $\mathbf{2 b} \quad$ Level of consensus +++

HRT may increase the risk of recurrence in women previously treated for breast cancer.

\section{Evidence-based recommendation 6.E19

Level of evidence Level of recom- \\ $2 \mathrm{~b}$ mendation A \\ Level of consensus \\ $+++$}

HRT must not be carried out in women who have had breast cancer. HRT may be considered in individual cases when non-hormonal therapies have failed and the patient is experiencing a significant reduction in her quality of life.

\section{Addendum}

The S3-guideline "Perimenopause and Postmenopause - Diagnosis and Interventions" was published in January 2020 (Oncology Guidelines Program, 2020). The comprehensive meta-analysis of prospective and retrospective data from observational studies and randomized studies on the association between perimenopausal and postmenopausal hormone therapy ( $\mathrm{HT})$ and the risk of breast cancer by the Collaborative Group on Hormonal Factors in Breast Cancer published in August 2019 was not yet included in the S3-guideline at the time of publication. Because of the relevance of the data, the authors of the S3-guideline "Perimenopause and Postmenopause - Diagnosis and Interventions", represented by the guideline's Steering Committee, updated the S3guideline by adding an addendum which states their position regarding the meta-analysis by the Collaborative Group on Hormonal Factors in Breast Cancer (Collaborative Group on Hormonal Factors in Breast Cancer, 2020).

The authors of the S3-guideline "Perimenopause and Postmenopause - Diagnosis and Interventions" are of the opinion that the figures given in > Table $\mathbf{1 4}$ are suitable when informing patients with menopausal symptoms seeking advice. After taking sequential combined HT for 5 years from the age of 50 , it is expected that there will 14 additional cases of breast cancer per 1000 women during the next 20 years. If treatment consists of continuous-combined HT, the number of additional women developing breast cancer is expected to be 20 , while estrogen therapy is considered to lead to an additional 5 cases with breast cancer. These risk figures are consistent with previously known data and should be used to advise patients prior to planning HT. Changes to the statements and recommendations published in the S3-guideline "Perimenopause and Postmenopause - Diagnosis and Interventions" (Oncology Guidelines Program, 2020) because of the results of the meta-analysis by the Collaborative Group on Hormonal Factors in Breast Cancer (Collaborative Group on Hormonal Factors in Breast Cancer, 2020) are not necessary. As regards the advice given to patients concerning the duration of planned HT, physicians should refer to $>$ Table 15 . Based on the results of the meta-analysis by the Collaborative Group on Hormonal Factors in Breast Cancer (Collaborative Group on Hormonal Factors in Breast Cancer, 2020), there is no increased risk of breast cancer in the 9 years after ending estrogen therapy if estrogen therapy only lasted for a maximum of 4 years (relative risk [RR] $1.07 ; 95 \%$ confidence interval $[\mathrm{Cl}] 0.96-1.20)$. After ending up to 4 years of combined EPT treatment (sequential combined HT or continuous-combined $\mathrm{HT}$ ), there is also no increased risk of breast cancer during the following 9 years (RR 1.06; $95 \% \mathrm{Cl} 0.98-1.15$ ) ( $\vee$ Table 15). However, the data of the Collaborative Group on Hormonal Factors in Breast Cancer point to an increased risk of being diagnosed with breast cancer during the time the patient 
- Table 14 Risk of breast cancer associated with a specific type of hormone treatment in perimenopause and postmenopause.

\begin{tabular}{|l|l|l|}
\hline Type of HT & $\begin{array}{l}\text { Additional cases of breast cancer over } \mathbf{2 0} \text { years per } \\
\mathbf{1 0 0 0} \text { women after } \mathbf{5} \text { years of } \mathbf{H T} \text { from the age of } \mathbf{5 0}\end{array}$ & $\begin{array}{l}\text { Additional cases of breast cancer over } \mathbf{2 0} \text { years per } \\
\mathbf{1 0 0 0} \text { women after } \mathbf{1 0} \text { years of } \mathbf{H T} \text { from the age of } \mathbf{5 0}\end{array}$ \\
\hline Sequential EPT & +14 & +29 \\
\hline $\begin{array}{l}\text { Continuous- } \\
\text { combined EPT }\end{array}$ & +20 & +40 \\
\hline ET & +5 & +11 \\
\hline
\end{tabular}

$\mathrm{HT}$ : hormone treatment, EPT: estrogen-progestogen therapy, ET: estrogen therapy

Data from: Collaborative Group on Hormonal Factors in Breast Cancer

- Table 15 Risk of breast cancer during hormone therapy in perimenopause and postmenopause and over the next 9 years after terminating hormone therapy in perimenopause and postmenopause.

\begin{tabular}{|c|c|c|}
\hline Type of HT & Relative risk of breast cancer during HT & $\begin{array}{l}\text { Relative risk of breast cancer } \\
\text { up to } 9 \text { years after the end of HT }\end{array}$ \\
\hline ET with $1-4$ years of treatment & RR $1.17 ; 95 \% \mathrm{Cl} 1.10-1.26$ & RR $1.07 ; 95 \% \mathrm{Cl} 0.96-1.20$ \\
\hline $\begin{array}{l}\text { EPT (continuous-combined or sequential } \\
\text { combined) with } 1-4 \text { years of treatment }\end{array}$ & RR $1.60 ; 95 \%$ Cl 1.52-1.69 & RR $1.06 ; 95 \% \mathrm{Cl} 0.98-1.15$ \\
\hline
\end{tabular}

is taking ET or EPT, starting already in the first year of therapy ( $\triangleright$ Table 15). The epidemiological data do not make it clear whether this is a biological effect or whether it merely reflects an increased probability of detection.

A total of 17 of the 25 mandate holders entitled to vote voted on and agreed to the addendum. There were no dissenting votes. Eight mandate holders did not vote (abstained). Of the 17 mandate holders who were entitled to vote and voted, 4 had a conflict of interest.

The results of the vote on the addendum showed a strong consensus.

\section{HRT and the risk of endometrial cancer}

\section{Evidence-based statement 6.57}

\section{Level of evidence 2}

\section{Level of consensus +++}

In non-hysterectomized women, HRT consisting only of an estrogen without the protection afforded by progestogens is a risk factor for developing endometrial cancer. The effect depends on the duration of hormone therapy.

\section{Evidence-based statement 6.58}

\section{Level of evidence 2}

Level of consensus ++

A reduction in the risk of endometrial cancer was observed for patients who took continuous-combined HRT with conjugated equine estrogens and medroxyprogesterone acetate as the progestogen, with an average duration of intake of 5.6 years.

\section{Evidence-based statement 6.59}

Level of evidence $2 \quad$ Level of consensus +++

Continuous-combined HRT for $<5$ years may be considered safe with regard to the risk of endometrial cancer.

\section{Evidence-based statement 6.510}

\begin{tabular}{l|l} 
Level of evidence 3 & Level of consensus ++
\end{tabular}

Long-term continuous-combined HRT for $>6$ years or $>10$ years may lead to an increased risk of endometrial cancer.

\section{Evidence-based statement 6.511}

\begin{tabular}{l|l} 
Level of evidence 4 & Level of consensus +
\end{tabular}

The use of progesterone or dydrogesterone in the context of continuous-combined HRT may increase the risk of developing endometrial cancer.

\section{Evidence-based statement 6.512}

\begin{tabular}{|l|l} 
Level of evidence 3 & Level of consensus ++
\end{tabular}

Sequential combined HRT may increase the risk of developing endometrial cancer. The effect depends on the duration, type, and dose of the progestogen. 


\section{Evidence-based statement 6.513}

Level of evidence 3

Level of consensus +++

Sequential combined HRT taken for less than 5 years and using a synthetic progestogen may be considered safe with regard to the risk of endometrial cancer.

\begin{tabular}{|c|c|c|}
\hline \multicolumn{3}{|c|}{ Evidence-based recommendation 6.E20 } \\
\hline $\begin{array}{l}\text { Level of evidence } \\
\text { LLA }\end{array}$ & $\begin{array}{l}\text { Level of recom- } \\
\text { mendation A }\end{array}$ & $\begin{array}{l}\text { Level of consensus } \\
++\end{array}$ \\
\hline
\end{tabular}

ET must only be taken by hysterectomized women. Combined EPT for non-hysterectomized women must include 10 days, or better 14 days, of a progestogen per treatment month.

\section{HRT after endometrial cancer}

\section{Evidence-based statement 6.S14}

\begin{tabular}{l|l} 
Level of evidence $2 b \quad$ Level of consensus +++
\end{tabular}

Whether taking HRT after prior treatment for endometrial cancer constitutes a risk has not yet been sufficiently investigated.

\begin{tabular}{|c|c|c|}
\hline \multicolumn{3}{|c|}{ Evidence-based recommendation 6.E21 } \\
\hline $\begin{array}{l}\text { Level of evidence } \\
2 \mathrm{~b}\end{array}$ & $\begin{array}{l}\text { Level of recom- } \\
\text { mendation EK }\end{array}$ & $\begin{array}{l}\text { Level of consensus } \\
++\end{array}$ \\
\hline
\end{tabular}

HRT may be considered for patients previously treated for endometrial cancer if the patients' menopausal symptoms significantly compromise their quality of life and non-hormonal alternatives have failed.

\section{Vaginal ET after endometrial cancer}

\begin{tabular}{l|l|l|} 
Evidence-based recommendation 6.E22 \\
\begin{tabular}{l|l|l} 
Level of evidence & $\begin{array}{l}\text { Level of recom- } \\
\text { mendation A }\end{array}$ & $\begin{array}{l}\text { Level of consensus } \\
++\end{array}$ \\
\hline 4
\end{tabular}
\end{tabular}

Symptoms of atrophic vaginitis in patients who were previously treated for endometrial cancer must be treated primarily using inert lubricating gels or creams.

\section{Consensus-based recommendation 6.E1}

Expert consensus

\section{Level of consensus ++}

Topical ET after primary therapy of endometrial cancer may be considered if the effect of treatment with inert lubricating gels or creams is not satisfactory.

\section{HRT and the risk of ovarian cancer}

Evidence-based recommendation 6.E23
\begin{tabular}{l|l|l} 
Level of evidence & $\begin{array}{l}\text { Level of recom- } \\
\text { mendation } \mathrm{A}\end{array}$ & $\begin{array}{l}\text { Level of consensus } \\
++\end{array}$ \\
\hline $2 \mathrm{a}$ &
\end{tabular}

Women who are considering HRT must be informed that ET or EPT may increase the risk of ovarian cancer. The effect may already appear when HRT is taken for less than 5 years and decreases again after hormone treatment is discontinued.
HRT after ovarian cancer

\section{Evidence-based statement 6.S15}

Level of evidence $\mathbf{2 b}$ Level of consensus ++

It is not possible to make any statements about the safety of taking HRT after treatment for ovarian cancer.

Evidence-based recommendation 6.E24
\begin{tabular}{l|l|l|}
\hline $\begin{array}{l}\text { Level of evidence } \\
\text { 2b }\end{array}$ & $\begin{array}{l}\text { Level of recom- } \\
\text { mendation } 0\end{array}$ & $\begin{array}{l}\text { Level of consensus } \\
+++\end{array}$ \\
\hline
\end{tabular}

HRT may be used to treat women previously treated for ovarian cancer after they have been properly informed about the risks.

\section{HRT and the risk of colorectal cancer}

\begin{tabular}{|c|c|c|}
\hline \multicolumn{3}{|c|}{ Evidence-based recommendation $6 . E 25$} \\
\hline $\begin{array}{l}\text { Level of evidence } \\
2 a\end{array}$ & $\begin{array}{l}\text { Level of recom- } \\
\text { mendation A }\end{array}$ & $\begin{array}{l}\text { Level of consensus } \\
+++\end{array}$ \\
\hline \multicolumn{3}{|c|}{$\begin{array}{l}\text { Women must be informed that HRT may reduce the risk of colorectal } \\
\text { cancer. This must not be construed as an indication for the preventative } \\
\text { use of HRT. }\end{array}$} \\
\hline
\end{tabular}

7 Primary ovarian insufficiency (POI)

\begin{tabular}{|c|c|c|}
\hline \multicolumn{3}{|c|}{ Evidence-based recommendation 7.E26 } \\
\hline $\begin{array}{l}\text { Level of evidence } \\
2 b\end{array}$ & $\begin{array}{l}\text { Level of recom- } \\
\text { mendation B }\end{array}$ & $\begin{array}{l}\text { Level of consensus } \\
++\end{array}$ \\
\hline \multicolumn{3}{|c|}{$\begin{array}{l}\text { Women with POI should be informed about the importance of taking } \\
\text { hormones, either in the form of HRT or in the form of combined oral } \\
\text { contraceptives (COCs), at least until the women reach the natural age } \\
\text { of menopause and as long as taking HRT or COCs is not contraindicated } \\
\text { for them. }\end{array}$} \\
\hline
\end{tabular}

\begin{tabular}{|c|c|}
\hline \multicolumn{2}{|c|}{ Evidence-based statement 7.S16 } \\
\hline Level of evidence $\mathbf{2 b}$ & Level of consensus ++ \\
\hline \multicolumn{2}{|c|}{$\begin{array}{l}\text { There is no clear-cut evidence that there is any difference in the efficacy } \\
\text { of treatment with HRT compared to the efficacy of combined oral } \\
\text { contraceptives. }\end{array}$} \\
\hline
\end{tabular}

\section{Conflict of Interest}

The conflicts of interest of the authors are listed in the long German-language version of this guideline.

\section{References}

The literature is listed in the long German-language version of this guideline. 


\section{Deutsche Version}

\section{Leitlinieninformationen}

\section{Leitlinienprogramm der DGGG, OEGGG und SGGG}

Informationen hierzu finden Sie am Ende der Leitlinie.

\section{Zitierweise}

Perimenopause and Postmenopause - Diagnosis and Interventions. Guideline of the DGGG and OEGGG (S3-Level, AWMF Registry Number 015-062, September 2020). Geburtsh Frauenheilk 2021; 81: 612-636

\section{Leitliniendokumente}

Die vollständige Langversion dieser Leitlinie sowie den Leitlinienreport inkl. einer Aufstellung der Interessenkonflikte aller Autoren können auf der Homepage der AWMF eingesehen werden: http://www.awmf.org/leitlinien/detail/I/015-062.html

\section{Leitliniengruppe}

Siehe $>$ Tab. 1 bis 4 .

- Tab. 1 Federführender und koordinierender Leitlinienautor.

\begin{tabular}{|l|l|}
\hline Autor & AWMF-Fachgesellschaft \\
\hline Prof. Dr. Olaf Ortmann & DGGG \\
\hline
\end{tabular}

Die folgenden Fachgesellschaften/Arbeitsgemeinschaften/Organisationen/Vereine haben Interesse an der Mitwirkung bei der Erstellung des Leitlinientextes und der Teilnahme an der Konsensuskonferenz bekundet und Vertreter für die Konsensuskonferenz benannt:

- Tab. 2 Repräsentativität der Leitliniengruppe: Beteiligung der Anwenderzielgruppe.

DGGG-Arbeitsgemeinschaft (AG)/

AWMF/Nicht-AWMF-Fachgesellschaft/Organisation/Verein

Arbeitsgemeinschaft Gynäkologische Onkologie (AGO)

Arbeitsgemeinschaft für Urogynäkologie und plastische

Beckenbodenrekonstruktion (AGUB)

Berufsverband der Frauenärzte (BVF)

D.A.CH-Gesellschaft Prävention von Herz-Kreislauf-Erkrankungen e. V.

Deutsche Gesellschaft für Allgemeinmedizin und Familienmedizin (DEGAM)

Deutsche Gesellschaft für Angiologie, Gesellschaft für Gefäßmedizin (DGA)

Deutsche Gesellschaft für Endokrinologie (DGE)
- Tab. 2 Repräsentativität der Leitliniengruppe: Beteiligung der Anwenderzielgruppe. (Fortsetzung)

DGGG-Arbeitsgemeinschaft (AG)/ AWMF/Nicht-AWMF-Fachgesellschaft/Organisation/Verein

Deutsche Gesellschaft für Gynäkologie, Endokrinologie und Fortpflanzungsmedizin (DGGEF)

Deutsche Gesellschaft für Gynäkologie und Geburtshilfe (DGGG)

Deutsche Gesellschaft für Hämatologie und Medizinische Onkologie (DGHO)

Deutsche Gesellschaft für Innere Medizin (DGIM)

Deutsche Gesellschaft für Kardiologie - Herz- und Kreislaufforschung (DGK)

Deutsche Gesellschaft für Neurologie (DGN)

Deutsche Gesellschaft für Pharmakologie (DGP)

Deutsche Gesellschaft für psychosomatische Frauenheilkunde und Geburtshilfe (DGPFG)

Deutsche Gesellschaft für Psychiatrie und Psychotherapie,

Psychosomatik und Nervenheilkunde (DGPPN)

Deutsche Gesellschaft für Senologie (DGS)

Deutsche Krebsgesellschaft (DKG)

Deutsche Menopause Gesellschaft (DMG)

Dachverband Osteologie (DVO)

European Menopause and Andropause Society (EMAS)

Frauenselbsthilfe nach Krebs

Gesellschaft für Phytotherapie (GPT)

International Menopause Society (IMS)

Österreichische Gesellschaft für Gynäkologie und Geburtshilfe (OEGGG)

Schweizerische Gesellschaft für Gynäkologie und Geburtshilfe (SGGG)

Die SGGG hat zum Thema zwei Expertenbriefe, welche von den entsprechenden Expertinnen und Experten als weiterhin bestimmend für die Schweiz (deutsche und romanische Schweiz) erklärt wurden. Deshalb hat der Vorstand der SGGG auf Anraten der AGER beschlossen, die S3-Leitlinie „Peri- und Postmenopause“ nicht zu übernehmen.

Die Moderation der Leitlinie wurde dankenswerterweise von Frau Dr. M. Nothacker (AWMF-zertifizierter Leitlinienberater/ -moderator) übernommen.

- Tab. 3 Repräsentativität der Leitliniengruppe: Beteiligung der Patientenzielgruppe.

\section{AWMF/Nicht-AWMF-Fachgesellschaft/Organisation/Verein}

Frauenselbsthilfe nach Krebs e. V. 
- Tab. 4 Beteiligte Leitlinienautoren/innen (alphabetisch geordnet).

\begin{tabular}{|c|c|}
\hline $\begin{array}{l}\text { Autor/in } \\
\text { Mandatsträger/in }\end{array}$ & $\begin{array}{l}\text { DGGG-Arbeitsgemeinschaft (AG)/ } \\
\text { AWMF/Nicht-AWMF-Fach- } \\
\text { gesellschaft/Organisation/Verein }\end{array}$ \\
\hline Dr. med. C. Albring & BVF, Mitglied der Steuergruppe \\
\hline Prof. Dr. E. Baum & DEGAM \\
\hline Dr. med. M. Beckermann & DGPFG \\
\hline Prof. Dr. K. Bühling & D.A.CH \\
\hline Prof. Dr. G. Emons & DGGG \\
\hline Prof. Dr. T. Gudermann & DGP \\
\hline Prof. Dr. P. Hadji & DVO \\
\hline Prof. Dr. B. Imthurn & SGGG \\
\hline PD Dr. med. E. C. Inwald & 2. Leitlinienkoordinatorin \\
\hline Prof. Dr. L. Kiesel & DMG, Mitglied der Steuergruppe \\
\hline Prof. Dr. D. Klemperer & Experte, Patientinneninformation \\
\hline Dr. P. Klose & $\begin{array}{l}\text { Mandatsträgerin in Vertretung } \\
\text { von Prof. Langhorst, GPT }\end{array}$ \\
\hline Dr. med. K. König & BVF \\
\hline Prof. Dr. S. Krüger & DGPPN \\
\hline Prof. Dr. J. Langhorst & GPT \\
\hline Prof. Dr. M. Leitzmann & Experte, Epidemiologie \\
\hline Prof. Dr. A. Ludolph & DGN \\
\hline Prof. Dr. D. Lüftner & DGHO \\
\hline Frau D. Müller & Frauenselbsthilfe nach Krebs \\
\hline Prof. Dr. J. Neulen & DGGEF \\
\hline Dr. med. M. Nothacker & AWMF \\
\hline Prof. Dr. O. Ortmann & $\begin{array}{l}\text { Leitlinienkoordinator, federführender } \\
\text { Leitlinienautor, Mitglied der Steuer- } \\
\text { gruppe }\end{array}$ \\
\hline $\begin{array}{l}\text { Prof. Dr. E. Petri } \\
\text { (verstorben am } \\
21.09 .2019 \text { ) }\end{array}$ & AGUB \\
\hline Dr. med. H. Prautzsch & DEGAM \\
\hline Prof. Dr. F. Regitz-Zagrosek & DGK \\
\hline Dr. med. K. Schaudig & $\begin{array}{l}\text { Expertin, Gynäkologische } \\
\text { Endokrinologie }\end{array}$ \\
\hline Prof. Dr. F. Schütz & DGS \\
\hline Dr. med. A. Schwenkhagen & $\begin{array}{l}\text { Expertin, Gynäkologische } \\
\text { Endokrinologie }\end{array}$ \\
\hline Prof. Dr. T. Strowitzki & DGE \\
\hline Prof. Dr. P. Stute & EMAS, Mitglied der Steuergruppe \\
\hline Prof. Dr. B.-M. Taute & DGA \\
\hline Prof. Dr. C. Tempfer & AGO \\
\hline Prof. Dr. C. von Arnim & DGN \\
\hline Prof. Dr. L. Wildt & OEGGG \\
\hline Prof. Dr. E. Windler & DGIM, Mitglied der Steuergruppe \\
\hline
\end{tabular}

II

\section{Leitlinienverwendung}

\section{Fragestellung und Ziele}

Die Leitliniengruppe hat einvernehmlich Fragestellungen zu den folgenden Themenbereichen erarbeitet:

- Diagnostik und therapeutische Interventionen bei peri- und postmenopasualen Frauen

- Urogynäkologie

- kardiovaskuläre Erkrankungen

- Osteoporose

- Demenz, Depression, Stimmungsschwankungen

- HRT und Krebsrisiko

- prämature Ovarialinsuffizienz (POI)

- andere Erkrankungen

\section{Versorgungsbereich}

- stationärer Versorgungssektor

- ambulanter Versorgungssektor

\section{Anwenderzielgruppe/Adressaten}

Die Leitlinie richtet sich an Ärzte, die peri- und postmenopausale Frauen über die physiologischen Veränderungen sowie Störungen und deren Therapieoptionen beraten und behandeln:

- Gynäkologen in der Niederlassung

- Gynäkologen mit Klinikanstellung

- Ärzte, die peri- und postmenopausale Frauen beraten bzw. deren Beschwerden und Erkrankungen behandeln, wie z.B. Allgemeinärzte, Internisten, Psychiater, Neurologen, u. a.

\section{Verabschiedung und Gültigkeitsdauer}

Die Gültigkeit dieser Leitlinie wurde durch die Vorstände/Verantwortlichen der beteiligten Fachgesellschaften/Arbeitsgemeinschaften/Organisationen/Vereine sowie durch den Vorstand der DGGG und der DGGG-Leitlinienkommission sowie der OEGGG im Oktober und November 2018 bestätigt und damit in seinem gesamten Inhalt genehmigt. Die im Januar 2020 publizierte Leitlinie wurde im September 2020 um ein Addendum aktualisiert. Diese Leitlinie besitzt eine Gültigkeitsdauer vom 01.01 .2020 bis 31.12.2024. Diese Dauer ist aufgrund der inhaltlichen Zusammenhänge geschätzt.

Werden vor Ablauf der Gültigkeit Änderungen als erforderlich betrachtet, wird die Steuergruppe sich dazu beraten und mit der Leitliniengruppe Änderungsvorschläge in einem strukturierten Prozess abstimmen.

\section{Methodik}

\section{Grundlagen}

Die Methodik zur Erstellung dieser Leitlinie wird durch die Vergabe der Stufenklassifikation vorgegeben. Das AWMF-Regelwerk (Version 1.0) gibt entsprechende Regelungen vor. Es wird zwischen der niedrigsten Stufe (S1), der mittleren Stufe (S2) und der höchsten Stufe (S3) unterschieden. Die niedrigste Klasse definiert sich durch eine Zusammenstellung von Handlungsempfehlungen, erstellt durch eine nicht repräsentative Expertengruppe. Im Jahr 
2004 wurde die Stufe S2 in die systematische evidenzrecherchebasierte (S2e) oder strukturelle konsensbasierte Unterstufe (S2k) gegliedert. In der höchsten Stufe S3 vereinigen sich beide Verfahren.

Diese Leitlinie entspricht der Stufe: S3

\section{Evidenzgraduierung}

Zur Beurteilung der Evidenz (Level 1-5) wurde in dieser Leitlinie das Klassifikationssystem des Oxford Centre for Evidence-based Medicine in der letzten aktuellen Version aus dem Jahr 2009 benutzt ( $\triangleright$ Tab. 5).

- Tab. 5 Graduierung der Evidenz nach Oxford (März 2009).

\begin{tabular}{|c|c|c|c|c|c|}
\hline Level & $\begin{array}{l}\text { Therapy/prevention, } \\
\text { etiology/harm }\end{array}$ & Prognosis & Diagnosis & $\begin{array}{l}\text { Differential } \\
\text { diagnosis/symptom } \\
\text { prevalence study }\end{array}$ & $\begin{array}{l}\text { Economic and } \\
\text { decision analyses }\end{array}$ \\
\hline $1 \mathrm{a}$ & $\begin{array}{l}\text { SYSTEMATIC REVIEWS } \\
\text { (with homogeneity*) } \\
\text { of RANDOMIZED CON- } \\
\text { TROLLED TRIALS }\end{array}$ & $\begin{array}{l}\text { SYSTEMATIC REVIEWS } \\
\text { (with homogeneity*) } \\
\text { of inception cohort } \\
\text { studies; CLINICAL } \\
\text { DECISION RULE" } \\
\text { validated in different } \\
\text { populations }\end{array}$ & $\begin{array}{l}\text { SYSTEMATIC REVIEWS } \\
\text { (with homogeneity*) } \\
\text { of Level } 1 \text { diagnostic } \\
\text { studies; CLINICAL } \\
\text { DECISION RULE" with } \\
\text { 1b studies from differ- } \\
\text { ent clinical centers }\end{array}$ & $\begin{array}{l}\text { SYSTEMATIC REVIEWS } \\
\text { (with homogeneity*) } \\
\text { of prospective cohort } \\
\text { studies }\end{array}$ & $\begin{array}{l}\text { SYSTEMATIC REVIEWS } \\
\text { (with homogeneity*) } \\
\text { of Level } 1 \text { economic } \\
\text { studies }\end{array}$ \\
\hline $1 \mathrm{~b}$ & $\begin{array}{l}\text { Individual RANDOM- } \\
\text { IZED CONTROLLED } \\
\text { TRIALS (with narrow } \\
\text { confidence interval" } \mathrm{i} \text { ) }\end{array}$ & $\begin{array}{l}\text { Individual inception } \\
\text { cohort study with } \\
\text { > } 80 \% \text { follow-up; } \\
\text { CLINICAL DECISION } \\
\text { RULE" validated in } \\
\text { a single population }\end{array}$ & $\begin{array}{l}\text { Validating** cohort } \\
\text { study with good" " " } \\
\text { reference standards; } \\
\text { or CLINICAL DECISION } \\
\text { RULE" tested within } \\
\text { one clinical center }\end{array}$ & $\begin{array}{l}\text { Prospective cohort } \\
\text { study with good } \\
\text { follow-up**** }\end{array}$ & $\begin{array}{l}\text { Analysis based on } \\
\text { clinically sensible } \\
\text { costs or alternatives; } \\
\text { systematic review(s) of } \\
\text { the evidence; and } \\
\text { including multi-way } \\
\text { sensitivity analyses }\end{array}$ \\
\hline 1c & All-or-none§ & All-or-none case series & $\begin{array}{l}\text { Absolute SPins and } \\
\text { SNouts" " }\end{array}$ & All-or-none case series & $\begin{array}{l}\text { Absolute better- } \\
\text { value or worse-value } \\
\text { analyses" " " " " }\end{array}$ \\
\hline $2 a$ & $\begin{array}{l}\text { SYSTEMATIC REVIEWS } \\
\text { (with homogeneity*) } \\
\text { of cohort studies }\end{array}$ & $\begin{array}{l}\text { SYSTEMATIC REVIEWS } \\
\text { (with homogeneity*) } \\
\text { of either retrospective } \\
\text { cohort studies or un- } \\
\text { treated control groups } \\
\text { in RANDOMIZED CON- } \\
\text { TROLLED TRIALSs }\end{array}$ & $\begin{array}{l}\text { SYSTEMATIC REVIEWS } \\
\text { (with homogeneity*) }^{*} \\
\text { of level > } 2 \text { diagnostic } \\
\text { studies }\end{array}$ & $\begin{array}{l}\text { SYSTEMATIC REVIEWS } \\
\text { (with homogeneity*) } \\
\text { of } 2 \mathrm{~b} \text { and better studies }\end{array}$ & $\begin{array}{l}\text { SYSTEMATIC REVIEWS } \\
\text { (with homogeneity*) } \\
\text { of level > } 2 \text { economic } \\
\text { studies }\end{array}$ \\
\hline $2 b$ & $\begin{array}{l}\text { Individual cohort study } \\
\text { (including low quality } \\
\text { RANDOMIZED CON- } \\
\text { TROLLED TRIALS; } \\
\text { e.g., < } 80 \% \text { follow-up) }\end{array}$ & $\begin{array}{l}\text { Retrospective cohort } \\
\text { study or follow-up of } \\
\text { untreated control pa- } \\
\text { tients in RANDOMIZED } \\
\text { CONTROLLED TRIALS; } \\
\text { Derivation of CLINICAL } \\
\text { DECISION RULE" or } \\
\text { validated on split- } \\
\text { sample } \S \S \text { only }\end{array}$ & $\begin{array}{l}\text { Exploratory** cohort } \\
\text { study with good" " " } \\
\text { reference standards; } \\
\text { CLINICAL DECISION } \\
\text { RULE" after derivation, } \\
\text { or validated only } \\
\text { on split-sample }{ }^{\S \S} \text { or } \\
\text { databases }\end{array}$ & $\begin{array}{l}\text { Retrospective } \\
\text { cohort study, } \\
\text { or poor follow-up }\end{array}$ & $\begin{array}{l}\text { Analysis based on clini- } \\
\text { cally sensible costs or } \\
\text { alternatives; limited re- } \\
\text { view(s) of the evidence, } \\
\text { or single studies; and } \\
\text { including multi-way } \\
\text { sensitivity analyses }\end{array}$ \\
\hline $2 c$ & $\begin{array}{l}\text { "Outcomes" Research; } \\
\text { Ecological studies }\end{array}$ & “Outcomes” Research & & Ecological studies & $\begin{array}{l}\text { Audit or outcomes } \\
\text { research }\end{array}$ \\
\hline $3 a$ & $\begin{array}{l}\text { SYSTEMATIC REVIEWS } \\
\text { (with homogeneity*) } \\
\text { of case-control studies }\end{array}$ & & \multicolumn{3}{|c|}{ SYSTEMATIC REVIEWS (with homogeneity*) of 3b and better studies } \\
\hline $3 b$ & $\begin{array}{l}\text { Individual case-control } \\
\text { study }\end{array}$ & & $\begin{array}{l}\text { Non-consecutive } \\
\text { study; or without } \\
\text { consistently applied } \\
\text { reference standards }\end{array}$ & $\begin{array}{l}\text { Non-consecutive } \\
\text { cohort study, or very } \\
\text { limited population }\end{array}$ & $\begin{array}{l}\text { Analysis based on } \\
\text { limited alternatives } \\
\text { or costs, poor quality } \\
\text { estimates of data, but } \\
\text { including sensitivity } \\
\text { analyses incorporating } \\
\text { clinically sensible } \\
\text { variations. }\end{array}$ \\
\hline
\end{tabular}


\ Tab. 5 Graduierung der Evidenz nach Oxford (März 2009). (Fortsetzung)

\begin{tabular}{|c|c|c|c|c|c|}
\hline Level & $\begin{array}{l}\text { Therapy/prevention, } \\
\text { etiology/harm }\end{array}$ & Prognosis & Diagnosis & $\begin{array}{l}\text { Differential } \\
\text { diagnosis/symptom } \\
\text { prevalence study }\end{array}$ & $\begin{array}{l}\text { Economic and } \\
\text { decision analyses }\end{array}$ \\
\hline 4 & $\begin{array}{l}\text { Case series (and poor- } \\
\text { quality cohort and } \\
\text { case-control studies }^{\S \S} \text { ) }\end{array}$ & $\begin{array}{l}\text { Case series (and poor- } \\
\text { quality prognostic } \\
\text { cohort studies }^{* *} \text { ) }\end{array}$ & $\begin{array}{l}\text { Case-control study, } \\
\text { poor or non-indepen- } \\
\text { dent reference } \\
\text { standard }\end{array}$ & $\begin{array}{l}\text { Case series or } \\
\text { superseded reference } \\
\text { standards }\end{array}$ & $\begin{array}{l}\text { Analysis with no } \\
\text { sensitivity analysis }\end{array}$ \\
\hline 5 & \multicolumn{4}{|c|}{ Expert opinion without explicit critical appraisal, or based on physiology, bench research or "first principles" } & $\begin{array}{l}\text { Expert opinion } \\
\text { without explicit critical } \\
\text { appraisal, or based on } \\
\text { economic theory or } \\
\text { "first principles" }\end{array}$ \\
\hline
\end{tabular}

Quelle (Inhalt, Abkürzungen, Notes): http://www.cebm.net/?o=1025

\section{Empfehlungsgraduierung}

Während mit der Darlegung der Qualität der Evidenz (Evidenzstärke) die Belastbarkeit der publizierten Daten und damit das Ausmaß an Sicherheit/Unsicherheit des Wissens ausgedrückt wird, ist die Darlegung der Empfehlungsgrade Ausdruck des Ergebnisses der Abwägung erwünschter und unerwünschter Konsequenzen alternativer Vorgehensweisen.

Die Verbindlichkeit definiert die medizinische Notwendigkeit einer Leitlinienempfehlung, ihrem Inhalt zu folgen, wenn die Empfehlung dem aktuellen Stand der Wissenschaft entspricht. In nichtzutreffenden Fällen darf bzw. soll von der Empfehlung dieser Leitlinie abgewichen werden. Eine juristische Verbindlichkeit ist durch den Herausgeber nicht definierbar, weil dieser keine Gesetze, Richtlinien oder Satzungen (im Sinne des Satzungsrechtes) beschließen darf. Dieses Vorgehen wird vom obersten deutschen Gericht bestätigt (Bundesgerichtsurteil VI ZR 382/12).

Die reine Evidenzgraduierung einer Leitlinie auf S2e/S3-Niveau nach Oxford lässt einen leitlinientypischen Empfehlungsgrad zu. Dieser symbolische Empfehlungsgrad unterscheidet sich in $3 \mathrm{Ab}$ stufungen mit jeweils unterschiedlichen Stärken der sprachlichen Ausdrucksweise. Diese derzeit allgemein angewandte Graduierung wird außer von der AWMF auch von der Bundesärztekammer und ihren Nationalen Versorgungsleitlinien (NVL) benützt ( Tab. 6).

- Tab. 6 Graduierung von Empfehlungen (deutschsprachig).

\begin{tabular}{|l|l|l|}
\hline Symbolik & Beschreibung der Verbindlichkeit & Ausdruck \\
\hline A & $\begin{array}{l}\text { starke Empfehlung mit } \\
\text { hoher Verbindlichkeit }\end{array}$ & soll/soll nicht \\
\hline B & $\begin{array}{l}\text { einfache Empfehlung mit } \\
\text { mittlerer Verbindlichkeit }\end{array}$ & sollte/sollte nicht \\
\hline 0 & $\begin{array}{l}\text { offene Empfehlung mit } \\
\text { geringer Verbindlichkeit }\end{array}$ & kann/kann nicht \\
\hline
\end{tabular}

Die oben aufgeführte Einteilung von „Empfehlungen“ entspricht neben der Bewertung der Evidenz auch der klinischen Relevanz der zugrunde liegenden Studien und ihren nicht in der Graduierung der Evidenz aufgeführten Maße/Faktoren, wie die Wahl des Patientenkollektivs, Intention-to-treat oder Per-Protocol-Outcome-Analysen, ärztliches bzw. ethisches Handeln gegenüber dem Patienten, länderspezifische Anwendbarkeit usw. Demgegenüber kann eine starke, mäßige bzw. schwache Evidenzstärke entsprechend linear zu einer starken, einfachen bzw. offenen Empfehlung führen. Nur bei einer mittleren Evidenzstärke ist eine Höher- und Herabstufung in eine Grad-A- oder Grad-0-Empfehlung möglich. In besonderen Ausnahmefällen muss eine Graduierung der höchsten Evidenz zu einer schwächeren/offenen Empfehlung oder umgekehrt im Hintergrundtext begründet werden.

- starke Evidenzstärke

$\rightarrow$ Grad-A- oder Grad-B-Empfehlung

- mäßige Evidenzstärke

$\rightarrow$ Grad-A- oder Grad-B- oder Grad-0-Empfehlung

- schwache Evidenzstärke

$\rightarrow$ Grad-B- oder Grad-0-Empfehlung

\section{Statements}

Sollten fachliche Aussagen nicht als Handlungsempfehlungen, sondern als einfache Darlegung Bestandteil dieser Leitlinie sein, werden diese als „Statements“ bezeichnet. Bei diesen Statements ist die Angabe von Evidenzgraden nicht möglich.

\section{Konsensusfindung und Konsensusstärke}

Im Rahmen einer strukturellen Konsensusfindung (S2k/S3-Niveau) stimmen die berechtigten Teilnehmer der Sitzung die ausformulierten Statements und Empfehlungen ab. Hierbei kann es zu signifikanten Änderungen von Formulierungen etc. kommen. Abschließend wird abhängig von der Anzahl der Teilnehmer eine Stärke des Konsensus ermittelt ( $\bullet$ Tab. 7). 
- Tab. 7 Einteilung zur Zustimmung der Konsensusbildung.

\begin{tabular}{|c|c|c|}
\hline Symbolik & Konsensusstärke & prozentuale Übereinstimmung \\
\hline+++ & starker Konsens & $\begin{array}{l}\text { Zustimmung von } \\
>95 \% \text { der Teilnehmer }\end{array}$ \\
\hline++ & Konsens & $\begin{array}{l}\text { Zustimmung von } \\
>75-95 \% \text { der Teilnehmer }\end{array}$ \\
\hline+ & $\begin{array}{l}\text { mehrheitliche } \\
\text { Zustimmung }\end{array}$ & $\begin{array}{l}\text { Zustimmung von } \\
>50-75 \% \text { der Teilnehmer }\end{array}$ \\
\hline- & kein Konsens & $\begin{array}{l}\text { Zustimmung von } \\
<51 \% \text { der Teilnehmer }\end{array}$ \\
\hline
\end{tabular}

\section{Expertenkonsens}

Wie der Name bereits ausdrückt, sind hier Konsensusentscheidungen speziell für Empfehlungen/Statements ohne vorige systemische Literaturrecherche ( $\mathrm{S} 2 \mathrm{k}$ ) oder aufgrund von fehlender Evidenzen (S2e/S3) gemeint. Der zu benutzende Expertenkonsens (EK) ist gleichbedeutend mit den Begrifflichkeiten aus anderen Leitlinien wie „Good Clinical Practice“ (GCP) oder „klinischer Konsensuspunkt“ (KKP). Die Empfehlungsstärke graduiert sich gleichermaßen wie bereits im Kapitel Empfehlungsgraduierung beschrieben ohne die Benutzung der aufgezeigten Symbolik, sondern rein semantisch („soll“/,soll nicht“ bzw. „sollte“/,sollte nicht“ oder „kann“/,kann nicht“).

\section{Leitlinie}

1 Diagnostik und therapeutische Interventionen bei peri- und postmenopausalen Frauen

Diagnostik

\begin{tabular}{|l|l|l|}
\hline Evidenzbasierte Empfehlung 1.E1 \\
\hline Evidenzgrad LLA & $\begin{array}{l}\text { Empfehlungsgrad } \\
\text { A }\end{array}$ & $\begin{array}{l}\text { Konsensusstärke } \\
++\end{array}$ \\
\hline $\begin{array}{l}\text { Die Peri- und Postmenopause bei über 45-jährigen Frauen sollen } \\
\text { aufgrund klinischer Parameter diagnostiziert werden. }\end{array}$ \\
\hline
\end{tabular}

\begin{tabular}{|l|l|l|}
\hline \multicolumn{2}{|l|}{ Evidenzbasierte Empfehlung 1.E2 } \\
Evidenzgrad LLA & Empfehlungsgrad & $\begin{array}{l}\text { Konsensusstärke } \\
++\end{array}$ \\
& A & +
\end{tabular}

Eine Bestimmung des FSH zur Diagnose der Peri- und Postmenopause soll nur bei Frauen zwischen dem 40. und 45. Lebensjahr mit klimakterischen Symptomen (z. B. Hitzewallungen, Zyklusveränderungen) sowie bei Frauen unter 40 Jahren mit Hinweisen auf vorzeitige Ovarialinsuffizienz erfolgen.

\section{Therapeutische Interventionen}

\section{Evidenzbasierte Empfehlung 1.E3 Evidenzgrad 1a

Empfehlungsgrad \\ Konsensusstärke \\ A \\ $++$}

Frauen mit vasomotorischen Beschwerden soll eine HRT angeboten werden, nachdem sie über die kurz- (bis zu 5 Jahren) und langfristigen Nutzen und Risiken informiert wurden. Für nichthysterektomierte Frauen kommt eine EPT mit adäquatem Gestagenanteil, für hysterektomierte Frauen eine ET in Betracht.

Frauen sollten vor Beginn der Behandlung darauf hingewiesen werden, dass nach dem Absetzen der HRT vasomotorische Beschwerden wieder auftreten können.

\section{Evidenzbasierte Empfehlung 1.E4}

Evidenzgrad 3

Serotonin-Wiederaufnahmehemmer (SSRIs), Serotonin-NoradrenalinWiederaufnahmehemmer (SNRIs), Clonidin und Gabapentin sollen nicht routinemäßig als Mittel erster Wahl gegen vasomotorische Symptome angeboten werden.

\section{\begin{tabular}{|l|l|l|}
\hline \multicolumn{2}{|l|}{ Evidenzbasierte Empfehlung 1.E5 } \\
\hline Evidenzgrad 1b & Empfehlungsgrad & Konsensusstärke \\
& 0 & ++ \\
\hline
\end{tabular} \\ Kognitive Verhaltenstherapie (CBT), Isoflavone und Cimicifuga-Prä- parate können bei vasomotorischen Symptomen angewendet werden.}

Abweichende Meinung der Gesellschaft für Phytotherapie, siehe Langversion „Votum der Gesellschaft für Phytotherapie“ (GPT).

\section{Wirksamkeit und Sicherheit von Interventionen}

$\checkmark$ Tab. 8 und 9. 
- Tab. 8 Wirksamkeit und Risiken verschiedener Interventionen bei Hitzewallungen.

\begin{tabular}{|c|c|c|c|}
\hline & Nutzen nachgewiesen & Nutzen möglich & Nutzen unwahrscheinlich \\
\hline $\begin{array}{l}\text { geringes Risiko für Schaden } \\
\text { bzw. Therapieabbruch }\end{array}$ & $\begin{array}{l}\text { Abwarten bzw. Placebo, } \\
\text { CBT (Achtsamkeit, kognitive } \\
\text { und Verhaltenstherapie) }\end{array}$ & $\begin{array}{l}\text { Cimicifuga 5-6,5 mg/d (herbal preparation), } \\
\text { Isoflavone 30-80 mg/d, inkl. Phytoöstro- } \\
\text { gen-reiche Ernährung, Rotklee, S-Equol, } \\
\text { Genistein 30-60 mg/d, Rheum rhaponti- } \\
\text { kum, Akupunktur, Johanniskraut } 300 \text { mg/d }\end{array}$ & $\begin{array}{l}\text { Sport (3-6 Monate), Tiefen- } \\
\text { entspannung (4-12 Wochen), } \\
\text { Vitamin E }\end{array}$ \\
\hline $\begin{array}{l}\text { mittleres Risiko für Schaden } \\
\text { bzw. Therapieabbruch }\end{array}$ & Östrogene, Tibolon & SSRI, SNRI, Gabapentin, Clonidin & $\begin{array}{l}\text { DHEA } \\
\text { (Dehydroepiandrosteron) } \\
\text { Raloxifen }\end{array}$ \\
\hline $\begin{array}{l}\text { Risiko für Schaden nicht } \\
\text { ausreichend untersucht }\end{array}$ & & & $\begin{array}{l}\text { chinesische Kräuter im } \\
\text { Rahmen der TCM, Melatonin }\end{array}$ \\
\hline
\end{tabular}

- Tab. 9 Effektivität (Reduktion der Frequenz von Hitzewallungen) und die Wahrscheinlichkeit für einen Therapieabbruch verschiedener Interventionen im Vergleich zu Placebo für Frauen mit Uterus bei vasomotorischen peri- und postmenopausalen Symptomen.

\begin{tabular}{|l|l|l|}
\hline Intervention & $\begin{array}{l}\text { MR (mean ratio) } \\
\text { Effektivität }\end{array}$ & $\begin{array}{l}\text { OR (odds ratio) } \\
\text { Therapieabbruch* }\end{array}$ \\
\hline Östrogene plus Gestagene, nicht orale & $0,23(0,09-0,7)$ & \\
\hline Cimicifuga & $0,4(0,17-0,9)$ & $0,61(0,73-0,99)$ \\
\hline Östrogene plus Gestagene oral & $0,52(0,25-1,06)$ & $5,65(0,94-172,9)$ \\
\hline Tibolon & $0,55(0,24-1,29)$ & \\
\hline Akupunktur & $0,58(0,23-1,36)$ & $0,95(0,51-1,76)$ \\
\hline Isoflavone & $0,62(0,44-0,87)$ & $0,5(0,07-4,3)$ \\
\hline Kräutermischungen & $0,71(0,24-2,07)$ & $1,66(1,07-2,61)$ \\
\hline Scheinakupunktur & $0,75(0,19-1,9)$ & $1,58(0,42-6,66)$ \\
\hline SSRI/SNRIs & $0,84(0,54-1,31)$ & \\
\hline chinesische Kräuter & $0,95(0,46-1,9)$ & $0,31(0,1-1,0)$ \\
\hline Raloxifen & $1,65(0,61-4,51)$ & $0,88(0,63-1,23)$ \\
\hline CEE + Bazedoxifen & & $0,4(0,01-5,4)$ \\
\hline Gabapentin & & \\
\hline Baldrianwurzel & & \\
\hline * OR unter 1 bedeutet Therapietreue, über 1 Therapieabbruchrisiko. & \\
\hline
\end{tabular}

Veränderung der sexuellen Funktion

\section{Evidenzbasierte Empfehlung 1.E6 Evidenzgrad 1b Empfehlungsgrad 0 Konsensusstärke $++$}

Bei Frauen mit Libidoverlust in der Peri- und Postmenopause kann nach psychosexueller Exploration ggf. eine Testosterontherapie erwogen werden, wenn eine HRT nicht wirksam ist. Auf den Off-Label-Use soll hingewiesen werden.

Urogenitale Atrophie

\section{Evidenzbasierte Empfehlung 1.E7 Evidenzgrad 1b}

Frauen mit symptomatischer urogenitaler Atrophie soll die Anwendung von Befeuchtungs-, Gleitmitteln alleine oder zusammen mit einer vaginalen ET angeboten werden. Die Therapie kann so lange wie erforderlich angewendet werden.

Wenn Östrogene vaginal angewendet werden, sind östriolhaltige Präparate zu bevorzugen. Unter lokaler ET soll keine routinemäßige Vaginalsonografie zur Messung der Endometriumdicke durchgeführt werden (s. S3-Leitlinie Endometriumkarzinom AWMF-Registernummer 032-034). 


\section{Urogynäkologie}

\section{Belastungsinkontinenz}

\section{Evidenzbasiertes Statement 2.S1}

Evidenzgrad 1a

Konsensusstärke ++

Eine vaginale ET kann eine Harninkontinenz bei postmenopausalen Frauen verbessern.

\section{Evidenzbasierte Empfehlung 2.E8}

\begin{tabular}{|l|l|l|l|l|l}
\hline Evidenzgrad 1a & Empfehlungsgrad & Konsensusstärke \\
& A & ++
\end{tabular}

Patientinnen sollen vor einer systemischen ET/EPT darüber informiert werden, dass diese zum Auftreten oder zur Verschlechterung einer Harninkontinenz führen kann.

\section{Evidenzbasierte Empfehlung 2.E9}

Evidenzgrad 1a

Empfehlungsgrad

A

Konsensusstärke

$++$

Postmenopausalen Patientinnen mit Harninkontinenz sollen

Beckenbodentraining und eine vaginale ET angeboten werden.

Überaktive Blase

Evidenzbasiertes Statement 2.S2

Evidenzgrad $1 \mathrm{~b}$

Konsensusstärke +++

Eine systemische HRT kann eine vorhandene Harninkontinenz verschlechtern. Eine vaginale ET kann bei überaktiver Blase (OAB) angeboten werden.

\section{Evidenzbasierte Empfehlung 2.E10}

Evidenzgrad 1b

Empfehlungsgrad

Konsensusstärke

$++$

Wenn bei einer Drangsymptomatik urologische Erkrankungen ausgeschlossen wurden, kann eine lokale ET angeboten werden.

Miktionsfrequenz und Drangsymptomatik können reduziert werden.

\section{Rezidivierende Harnwegsinfekte}

\section{Evidenzbasiertes Statement 2.53}

Evidenzgrad 2b

Konsensusstärke ++

Die Veränderung des Vaginalmilieus postmenopausaler Frauen disponiert zu Harnwegsinfektionen. Es besteht eine positive Korrelation mit höherem Alter.

\section{Evidenzbasierte Empfehlung 2.E11}

Evidenzgrad 2a

B

$++$

Bei rezidivierenden Zystitiden postmenopausaler Frauen sollte vor Beginn einer antibiotischen Langzeitprävention eine vaginale ET durchgeführt werden.

\section{3}

\section{Kardiovaskuläre Erkrankungen}

\section{Evidenzbasierte Empfehlung 3.E12 \\ Evidenzgrad 2b

Empfehlungsgrad \\ Konsensusstärke \\ B

Das kardiovaskuläre Basisrisiko peri- und postmenopausaler Frauen variiert sehr stark in Abhängigkeit von den Risikofaktoren. Sie sollten optimal kontrolliert sein, damit sie keine Kontraindikation für eine HRT darstellen. Deshalb sollten die vaskulären Risikofaktoren vor Beginn einer HRT abgeklärt und behandelt werden ( $>$ Tab. 10).

> Tab. 10 Effekte einer oralen HRT auf kardiovaskuläre Erkrankungen in der Women's Health Initiative.

\begin{tabular}{|c|c|c|c|c|c|c|c|c|c|c|}
\hline & \multicolumn{5}{|l|}{ EPT } & \multicolumn{5}{|l|}{ ET } \\
\hline & Verum & $\begin{array}{l}\text { Kon- } \\
\text { trolle }\end{array}$ & HR & $95 \%-K I$ & p & Verum & $\begin{array}{l}\text { Kon- } \\
\text { trolle }\end{array}$ & HR & 95\%-KI & p \\
\hline $\begin{array}{l}\text { tiefe Venen- } \\
\text { thrombose }\end{array}$ & 122 & 61 & 1,87 & $1,37,2,54$ & $<0,001$ & 85 & 59 & 1,48 & $1,06,2,07$ & 0,02 \\
\hline Schlaganfall & 159 & 109 & 1,37 & $1,07,1,76$ & 0,01 & 169 & 130 & 1,35 & $1,07,1,70$ & 0,01 \\
\hline $\begin{array}{l}\text { koronare } \\
\text { Herzkrankheit }\end{array}$ & 196 & 159 & 1,18 & $0,95,1,45$ & 0,13 & 204 & 222 & 0,94 & $0,78,1,14$ & 0,53 \\
\hline $\begin{array}{l}\text { kardiovaskuläre } \\
\text { Mortalität }\end{array}$ & 79 & 70 & 1,05 & $0,76,1,45$ & 0,77 & 109 & 112 & 1,00 & $0,77,1,31$ & 0,98 \\
\hline Gesamtmortalität & 250 & 238 & 0,97 & $0,81,1,16$ & 0,76 & 301 & 299 & 1,03 & $0,88,1,21$ & 0,68 \\
\hline
\end{tabular}

Abkürzungen: Verum: 0,625 mg konjugierte Östrogene plus kontinuierlich 2,5 mg Medroxyprogesteronacetat, HR: Hazard Ratio,

95\%-KI: 95\%-Konfidenzintervall, p: Signifikanz. 


\section{Thromboembolien}

\section{Evidenzbasierte Empfehlung 3.E13}

Evidenzgrad 2a Empfehlungsgrad A

Konsensusstärke $++$

Frauen sollen darüber informiert werden, dass das Thromboembolierisiko unter oraler ET und EPT erhöht ist und höher ist als bei transdermaler Applikation.

\section{Zerebrovaskuläre Ereignisse}

\section{Evidenzbasierte Empfehlung 3.E14}

\begin{tabular}{|l|l|l|}
\hline Evidenzgrad 2b & Empfehlungsgrad & $\begin{array}{l}\text { Konsensusstärke } \\
++\end{array}$ \\
& A &
\end{tabular}

Frauen sollen darüber informiert werden, dass eine orale EPT das Risiko für ischämische zerebrovaskuläre Ereignisse möglicherweise erhöht, nicht aber eine transdermale ET. Das absolute Risiko für einen Schlaganfall ist bei jüngeren Frauen sehr niedrig.

Koronare Herzkrankheit

\section{Evidenzbasierte Empfehlung 3.E15}

Evidenzgrad 2b

\section{Empfehlungsgrad}

A

\section{Konsensusstärke}

$++$

Frauen sollen darüber informiert werden, dass eine EPT das kardiovaskuläre Risiko nicht oder nur geringfügig erhöht bzw. eine ET das kardiovaskuläre Risiko nicht erhöht oder verringert. Unter Berücksichtigung dieser Evidenz und der Risiken für Thromboembolien und ischämische Schlaganfälle ist eine HRT zur Prävention der koronaren Herzkrankheit ungeeignet und sollte zur Behandlung klimakterischer Beschwerden vor dem 60. Lebensjahr begonnen werden.

4

\section{Osteoporose}

\section{Evidenzbasiertes Statement 4.54}

Evidenzgrad 1a Konsensusstärke +++

Eine HRT führt zu einer signifikanten Erniedrigung des Risikos für Osteoporose-assoziierte Frakturen.

\section{Evidenzbasiertes Statement 4.55}

\section{Evidenzgrad 2a}

\section{Konsensusstärke ++}

Der frakturreduzierende Einfluss einer HRT war unabhängig von der Einnahmedauer (d. h. bereits nach einer kurzen < 1 -jährigen Einnahme nachweisbar) und des Alters bei Therapiebeginn. Zusätzlich scheint der frakturreduzierende Effekt nach Beendigung einer HRT in geringerem Maße weiter zu bestehen ( $\vee$ Tab. 11 und 12).
\ Tab. 11 Risikofaktoren für Osteoporose.

\begin{tabular}{|c|c|}
\hline Facharzt* gruppe & Risikofaktor \\
\hline $\begin{array}{l}\text { Allgemeine } \\
\text { Risikofaktoren/ } \\
\text { Allgemeinmedizin }\end{array}$ & $\begin{array}{l}\text { - Alter (2- bis 4-fach pro Dekade ab 50) } \\
\text { - Geschlecht (Frau/Mann: } 2 \text { zu 1) } \\
\text { - prävalente WK-Frakturen (2- bis 10-fach) } \\
\text { - } \text { niedrigtraumatische periphere Fraktur } \\
\text { - proximale Femurfraktur bei Vater oder Mutter } \\
\text { - } \text { multiple Stürze } \\
\text { - Immobilität } \\
\text { - Nikotinkonsum } \\
\text { - Untergewicht (BMI <20) } \\
\text { - } \text { Cortisontherapie > } 3 \text { Monate > 2,5 mg }\end{array}$ \\
\hline Endokrinologie & $\begin{array}{l}\text { - Cushing-Syndrom } \\
\text { - primärer Hyperparathyreoidismus } \\
\text { - Wachstumshormonmangel bei } \\
\text { Hypophyseninsuffizienz } \\
\text { - Hyperthyreose } \\
\text { - Diabetes mellitus Typ } 1 \text { oder } 2 \\
\text { - Glidazontherapie }\end{array}$ \\
\hline Gastroenterologie & $\begin{array}{l}\text { - Bll-Magenresektion oder Gastrektomie } \\
\text { - Zöliakie } \\
\text { - Protonenpumpenhemmer }\end{array}$ \\
\hline Geriatrie & $\begin{array}{l}\text { - Sedativa } \\
\text { - Neuroleptika } \\
\text { - Benzodiazepine }\end{array}$ \\
\hline Gynäkologie & $\begin{array}{l}\text { - Aromatasehemmer } \\
\text { - Hypogonadismus }\end{array}$ \\
\hline Kardiologie & - Herzinsuffizienz \\
\hline Neurologie & $\begin{array}{l}\text { - Epilepsie und Antiepileptika } \\
\text { - Depression und Antidepressiva }\end{array}$ \\
\hline Pulmonologie & - COPD \\
\hline $\begin{array}{l}\text { Rheumatologie/ } \\
\text { Orthopädie }\end{array}$ & $\begin{array}{l}\text { - rheumatoide Arthritis } \\
\text { - Spondylitis ankylosans }\end{array}$ \\
\hline
\end{tabular}

- Tab. 12 Aktuelle Behandlungsmöglichkeiten der Osteoporose bei Frauen nach den Wechseljahren.

\begin{tabular}{|l|l|l|l|}
\hline $\begin{array}{l}\text { Anti- } \\
\text { resorptiva }\end{array}$ & $\begin{array}{l}\text { Evidenz für } \\
\text { weniger } \\
\text { Wirbelkörper- } \\
\text { frakturen }\end{array}$ & $\begin{array}{l}\text { weniger } \\
\text { periphere } \\
\text { Frakturen }\end{array}$ & $\begin{array}{l}\text { weniger } \\
\text { proximale } \\
\text { Femur- } \\
\text { frakturen }\end{array}$ \\
\hline Aledronat & $\mathrm{A}$ & $\mathrm{A}$ & $\mathrm{A}$ \\
\hline Ibadronat & $\mathrm{A}$ & $\mathrm{B}$ & - \\
\hline Risedronat & $\mathrm{A}$ & $\mathrm{A}$ & $\mathrm{A}$ \\
\hline Zoledronat & $\mathrm{A}$ & $\mathrm{A}$ & $\mathrm{A}$ \\
\hline Denosumab & $\mathrm{A}$ & $\mathrm{A}$ & $\mathrm{A}$ \\
\hline Bazedoxifen & $\mathrm{A}$ & $\mathrm{B}$ & - \\
\hline Raloxifen & $\mathrm{A}$ & $\mathrm{B}$ & - \\
\hline Östrogene & $\mathrm{A}$ & $\mathrm{A}$ & $\mathrm{A}$ \\
\hline & & & \\
\hline
\end{tabular}




\section{Stimmungsschwankungen}

\begin{tabular}{|l|l|l|l|}
\hline \multicolumn{3}{|l}{ Evidenzbasierte Empfehlung 5.E16 } \\
\begin{tabular}{|l|l|l|} 
Evidenzgrad LLA & Empfehlungsgrad & Konsensusstärke \\
+++
\end{tabular} \\
\hline
\end{tabular}

Frauen in der Peri- und Postmenopause sollen darüber beraten werden, dass es unklar ist, ob eine HRT vor dem 65. Lebensjahr das Demenzrisiko beeinflusst.

\begin{tabular}{|l|l|l|}
\hline \multicolumn{2}{|l|}{ Evidenzbasierte Empfehlung 5.E17 } \\
\begin{tabular}{|l|l|l|} 
Evidenzgrad LLA & Empfehlungsgrad & Konsensusstärke \\
& A & ++ \\
\hline
\end{tabular}
\end{tabular}

Die Indikation zur pharmakologischen Behandlung von Depressionen in der Perimenopause soll den allgemeinen Behandlungsleitlinien folgen (es liegen keine direkten Wirksamkeitsstudien in der Perimenopause vor).

Es gibt derzeit keine sicheren Hinweise auf eine unterschiedliche Wirksamkeit von Antidepressiva in Abhängigkeit vom Menopausenstatus. Es liegt keine ausreichende Evidenz zur Empfehlung einer HRT oder Psychotherapie zur Behandlung perimenopausaler Depressionen vor.

\section{$6 \quad$ HRT und Krebsrisiko}

HRT und Brustkrebsrisiko

\begin{tabular}{|c|c|c|}
\hline \multicolumn{3}{|c|}{ Evidenzbasierte Empfehlung 6.E18 } \\
\hline Evidenzgrad 1a & $\begin{array}{l}\text { Empfehlungsgrad } \\
\text { A }\end{array}$ & $\begin{array}{l}\text { Konsensusstärke } \\
++\end{array}$ \\
\hline
\end{tabular}

Frauen, die eine HRT erwägen, sollen darüber aufgeklärt werden, dass eine HRT (EPT/ET) zu einer geringen oder keiner Erhöhung des Brustkrebsrisikos führen kann. Die mögliche Risikoerhöhung ist abhängig von der Zusammensetzung der HRT, der Behandlungsdauer und reduziert sich nach Absetzen der HRT ( $\bullet$ Tab. 13).

- Tab. 13 Absolutes Brustkrebsrisiko für unterschiedliche Formen der HRT: Unterschiede der Brustkrebsinzidenz pro 1000 postmenopausale Frauen in 7,5 Jahren (95\%-KI).

\begin{tabular}{|l|l|l|}
\hline HRT-Typ & Studientyp & Current Use \\
\hline ET & RCT & 4 weniger $(-11$ bis +8$)$ \\
\hline & Beobachtungsstudie & 6 mehr (1 bis 12) \\
\hline EPT & RCT & 5 mehr $(-4$ bis 36) \\
\hline & Beobachtungsstudie & 17 mehr (14 bis 20) \\
\hline
\end{tabular}

HRT nach Mammakarzinom

Evidenzbasiertes Statement 6.56

Evidenzgrad $2 b$

Konsensusstärke +++

Eine HRT kann das Risiko für ein Rezidiv nach behandeltem Mammakarzinom steigern.

\section{Evidenzbasierte Empfehlung 6.E19}

Evidenzgrad 2b

Empfehlungsgrad

A

Konsensusstärke

$+++$

Eine HRT soll bei Frauen nach einem Mammakarzinom nicht durchgeführt werden. Im Einzelfall kann sie nach Versagen nichthormonaler Therapien und bei erheblicher Einschränkung der Lebensqualität erwogen werden.

\section{Addendum}

Im Januar 2020 wurde die S3-Leitlinie „Peri- und Postmenopause - Diagnostik und Interventionen“ publiziert (Leitlinienprogramm Onkologie, 2020). Die im August 2019 von der Collaborative Group on Hormonal Factors in Breast Cancer publizierte umfassende Metaanalyse prospektiver und retrospektiver Beobachtungsdaten sowie randomisierter Studiendaten zur Assoziation zwischen einer peri- und postmenopausalen Hormontherapie (HT) und dem Brustkrebsrisiko wurde in der S3-Leitlinie zum Zeitpunkt der Publikation noch nicht berücksichtigt. Aufgrund der Relevanz dieser Daten aktualisieren die Autoren der S3-Leitlinie „Peri- und Postmenopause - Diagnostik und Interventionen“, vertreten durch die Steuergruppe der Leitlinie, die S3-Leitlinie um ein Addendum, welches zur Metaanalyse der Collaborative Group on Hormonal Factors in Breast Cancer Stellung nimmt (Collaborative Group on Hormonal Factors in Breast Cancer, 2020).

Zur Aufklärung von ratsuchenden Patientinnen mit klimakterischen Beschwerden halten die Autoren der S3-Leitlinie „Peri- und Postmenopause - Diagnostik und Interventionen“ die in > Tab. 14 aufgelisteten Zahlen für geeignet. Nach 5 Jahren einer sequenziellen kombinierten HT mit Beginn ab dem 50. Lebensjahr ist für die nächsten 20 Jahre pro 1000 Frauen mit 14 zusätzlichen Fällen von Brustkrebs zu rechnen. Im Falle einer kontinuierlich-kombinierten HT ist mit 20 zusätzlichen Brustkrebsfällen zu rechnen, im Falle einer Östrogentherapie mit 5 zusätzlichen Brustkrebsfällen. Diese Risikoangaben stehen im Einklang mit den bisher bekannten Daten und sind für eine Aufklärung vor einer geplanten HT geeignet. Eine Änderung der in der S3-Leitlinie „Peri- und Postmenopause - Diagnostik und Interventionen“ publizierten Stellungnahmen und Empfehlungen (Leitlinienprogramm Onkologie, 2020) ist aufgrund der Ergebnisse der Metaanalyse der Collaborative Group on Hormonal Factors in Breast Cancer (Collaborative Group on Hormonal Factors in Breast Cancer, 2020) nicht erforderlich. Zur Beratung von Patientinnen hinsichtlich der Dauer einer geplanten HT wird auf $>$ Tab. 15 verwiesen. Aufgrund der Ergebnisse der Metaanalyse der Collaborative Group on Hormonal Factors in Breast Cancer (Collaborative Group on Hormonal Factors in Breast Cancer, 2020) ist für die folgenden 9 Jahre nach Abschluss einer Östrogentherapie von bis zu 4 Jahren Therapiedauer mit keinem erhöhten Brustkrebsrisiko zu rechnen (relatives Risiko [RR] 1,07; 95\%-Konfidenzintervall [KI] 0,96-1,20). Nach Abschluss einer kombinierten EPT (sequenziell kombinierte HT oder kontinuierlich kombinierte HT) von bis zu 4 Jahren Therapiedauer ist für die folgenden 9 Jahre ebenfalls mit keinem Brustkrebsrisiko zu rechnen (RR 1,06; 95\%-KI 0,98-1,15) ( $\triangleright$ Tab. 15). Allerdings weisen die Daten der Collaborative Group on Hormonal Factors in Breast Cancer für die Zeit während der Anwendung einer ET und einer EPT bereits ab dem 1. Anwendungsjahr ein erhöhtes Risiko für die Diagnose einer Brustkrebserkrankung auf ( $\triangleright$ Tab. 15). Ob dies einen biologischen Effekt oder eine erhöh- 
- Tab. 14 Risiko für Brustkrebs assoziiert mit einer Hormontherapie in der Peri- und Postmenopause.

\begin{tabular}{|c|c|c|}
\hline Art der HT & $\begin{array}{l}\text { zusätzliche Brustkrebsfälle im Laufe von } 20 \text { Jahren/ } \\
1000 \text { Frauen nach } 5 \text { Jahren HT ab dem } 50 \text {. Lebensjahr }\end{array}$ & $\begin{array}{l}\text { zusätzliche Brustkrebsfälle im Laufe von } 20 \text { Jahren/ } \\
1000 \text { Frauen nach } 10 \text { Jahren HT ab dem } 50 \text {. Lebensjahr }\end{array}$ \\
\hline sequenzielle EPT & +14 & +29 \\
\hline $\begin{array}{l}\text { kontinuierlich- } \\
\text { kombinierte EPT }\end{array}$ & +20 & +40 \\
\hline ET & +5 & +11 \\
\hline \multicolumn{3}{|c|}{ HT: Hormontherapie, EPT: Östrogen-Gestagen-Therapie, ET: Östrogentherapie } \\
\hline \multicolumn{3}{|c|}{ Angaben basierend auf: Collaborative Group on Hormonal Factors in Breast Cancer } \\
\hline
\end{tabular}

- Tab. 15 Risiko für Brustkrebs während einer Hormontherapie in der Peri- und Postmenopause und für die folgenden 9 Jahre nach Abschluss einer Hormontherapie in der Peri- und Postmenopause.

\begin{tabular}{l|l|l|}
\hline Art der HT & $\begin{array}{l}\text { relatives Brustkrebsbrisiko } \\
\text { während einer HT }\end{array}$ & $\begin{array}{l}\text { relatives Brustkrebsbrisiko bis } \mathbf{9} \text { Jahre } \\
\text { nach Abschluss einer HT }\end{array}$ \\
\hline $\begin{array}{l}\text { ET mit 1-4 Jahren Therapiedauer } \\
\text { RR 1,17; 95\%-KI 1,10-1,26 }\end{array}$ & RR 1,07; 95\%-KI 0,96-1,20 \\
\hline $\begin{array}{l}\text { EPT (kontinuierlich kombiniert oder sequenziell } \\
\text { kombiniert) mit 1-4 Jahren Therapiedauer }\end{array}$ & RR 1,60; 95\%-KI 1,52-1,69; 95\%-KI 0,98-1,15 \\
\hline $\begin{array}{l}\text { HT: Hormontherapie, ET: Östrogentherapie, EPT: Östrogen-Gestagen-Therapie, RR: relatives Risiko, KI: Konfidenzintervall } \\
\text { Angaben basierend auf: Collaborative Group on Hormonal Factors in Breast Cancer }\end{array}$
\end{tabular}

te Detektionswahrscheinlichkeit widerspiegelt, kann aufgrund von epidemiologischen Daten nicht geklärt werden.

Von den 25 stimmberechtigten Mandatsträgern haben 17 abgestimmt und zugestimmt. Es gab keine Gegenstimme. Acht Mandatsträger haben nicht abgestimmt (Enthaltung). Von den 17 stimmberechtigen Mandatsträgern, die abgestimmt hatten, hatten 4 einen Interessenkonflikt.

Abstimmungsergebnis für das Addendum: starker Konsens.

\section{HRT und Endometriumkarzinomrisiko}

\section{Evidenzbasiertes Statement 6.S7}

\section{Evidenzgrad 2}

\section{Konsensusstärke +++}

Eine alleinige HRT mit Östrogenen ohne Gestagenschutz ist bei nicht hysterektomierten Frauen ein Risikofaktor für das Auftreten eines Endometriumkarzinoms. Der Effekt ist von der Dauer der Anwendung abhängig.

\section{Evidenzbasiertes Statement 6.58}

\section{Evidenzgrad 2}

\section{Konsensusstärke ++}

Bei einer kontinuierlich kombinierten HRT mit konjugierten equinen Östrogenen und Medroxyprogesteronacetat als Gestagen mit durchschnittlich 5,6 Jahren Anwendungsdauer wurde eine Reduktion des Endometriumkarzinomrisikos beobachtet.

\section{Evidenzbasiertes Statement 6.59}

Evidenzgrad 2

\section{Konsensusstärke +++}

Eine kontinuierlich-kombinierte HRT mit < 5 Jahren Anwendungsdauer kann hinsichtlich des Endometriumkarzinomrisikos als sicher angesehen werden.

\section{Evidenzbasiertes Statement 6.S10}

\begin{tabular}{l|l} 
Evidenzgrad 3 & Konsensusstärke ++
\end{tabular}

Die Langzeitanwendung einer kontinuierlich-kombinierten HRT $>6$ Jahre bzw. > 10 Jahre kann zu einem erhöhten Endometriumkarzinomrisiko führen.

\section{Evidenzbasiertes Statement 6.S11}

\begin{tabular}{|l|l}
\hline Evidenzgrad 4 & Konsensusstärke + \\
\hline
\end{tabular}

Die Verwendung von Progesteron oder Dydrogesteron im Rahmen einer kontinuierlich-kombinierten HRT kann das Risiko der Entstehung eines Endometriumkarzinoms erhöhen.

\section{Evidenzbasiertes Statement 6.S12}

\begin{tabular}{l|l} 
Evidenzgrad 3 & Konsensusstärke ++
\end{tabular}

Die sequenziell-kombinierte HRT kann das Risiko der Entstehung eines Endometriumkarzinoms erhöhen. Der Effekt ist von der Dauer, Art und Dosis der Gestagenanwendung abhängig.

\section{Evidenzbasiertes Statement 6.S13}

Evidenzgrad 3

\section{Konsensusstärke +++}

Die sequenziell-kombinierte HRT mit einer Anwendungsdauer unter 5 Jahren und unter Verwendung eines synthetischen Gestagens kann hinsichtlich des Endometriumkarzinomrisikos als sicher angesehen werden. 


\section{Evidenzbasierte Empfehlung 6.E20}

Evidenzgrad LLA Empfehlungsgrad

Konsensusstärke

$++$

Eine ET soll nur bei hysterektomierten Frauen durchgeführt werden. Eine kombinierte EPT bei nicht hysterektomierten Frauen soll eine mindestens 10-, besser 14-tägige Gestagenanwendung pro Behandlungsmonat enthalten.

\section{HRT nach Endometriumkarzinom}

\section{Evidenzbasiertes Statement 6.514}

Evidenzgrad $2 b$ Konsensusstärke +++

Das Risiko einer HRT nach behandeltem Endometriumkarzinom ist nicht ausreichend untersucht.

\section{Evidenzbasierte Empfehlung 6.E21}

Evidenzgrad $2 b$

Empfehlungsgrad

EK

Konsensusstärke

Bei Patientinnen mit behandeltem Endometriumkarzinom kann eine HRT bei klimakterischen Beschwerden mit erheblichen Einschränkungen der Lebensqualität und Versagen nicht hormonaler Alternativen erwogen werden.

\section{Vaginale ET nach Endometriumkarzinom}

\section{Evidenzbasierte Empfehlung 6.E22}

Evidenzgrad 4 Empfehlungsgrad

A

Konsensusstärke

$++$

Symptome einer atrophen Vaginitis bei Patientinnen nach Therapie eines Endometriumkarzinoms sollen primär mit inerten Gleitgelen oder Cremes behandelt werden.

Konsensbasierte Empfehlung 6.E1

Expertenkonsens

Konsensusstärke ++

Eine lokale ET nach Primärtherapie eines Endometriumkarzinoms kann nach nicht zufriedenstellender Behandlung mit inerten Gleitgelen oder

Cremes erwogen werden.

\section{HRT und Ovarialkarzinomrisiko}

\section{Evidenzbasierte Empfehlung 6.E23}

\section{Evidenzgrad 2a}

Empf

\section{Konsensusstärke}

$++$

Frauen, die eine HRT erwägen, sollen darüber aufgeklärt werden, dass eine ET bzw. EPT das Ovarialkarzinomrisiko erhöhen können. Die Wirkung kann bereits bei Anwendungszeiten von unter 5 Jahren auftreten und reduziert sich nach Absetzen der Therapie.

\section{HRT nach Ovarialkarzinom}

\section{Evidenzbasiertes Statement 6.S15}

\begin{tabular}{l|l}
\hline Evidenzgrad 2b & Konsensusstärke ++
\end{tabular}

Zur Sicherheit einer HRT nach Behandlung eines Ovarialkarzinoms kann keine zuverlässige Aussage gemacht werden.

\section{Evidenzbasierte Empfehlung 6.E24}

Evidenzgrad 2b
Empfehlungsgrad

0

\section{Konsensusstärke}

$+++$
Eine HRT kann bei Frauen nach Behandlung eines Ovarialkarzinoms nach entsprechender Aufklärung durchgeführt werden.

\section{HRT und Risiko für kolorektale Karzinome}

\section{Evidenzbasierte Empfehlung 6.E25}

Evidenzgrad 2a

\section{A}

$+++$

Frauen sollen darüber aufgeklärt werden, dass eine HRT das Risiko für kolorektale Karzinome senken kann. Daraus ergibt sich keine Indikation für einen präventiven Einsatz der HRT.

7 Prämature Ovarialinsuffizienz (POI)

\section{Evidenzbasierte Empfehlung 7.E26}

Evidenzgrad 2 Empfehlungsgrad B

Konsensusstärke $++$

Frauen mit POI sollten über die Wichtigkeit einer hormonellen Behandlung mit einer HRT oder kombinierten oralen Kontrazeptiva (OC) zumindest bis zum natürlichen Menopausenalter aufgeklärt werden, sofern keine Kontraindikationen gegen eine HRT oder kombinierte OC vorliegen.

\section{Evidenzbasiertes Statement 7.S16}

Evidenzgrad $2 b$ Konsensusstärke ++

Es gibt keine eindeutigen Belege für Unterschiede in der Wirksamkeit einer Behandlung mit einer HRT oder kombinierten oralen Kontrazeptiva.

Interessenkonflikt

Die Interessenkonflikte der Autoren sind in der deutschen Langfassung der Leitlinie aufgelistet.

\section{Literatur}

Bezüglich der Literaturangaben verweisen wir auf die deutsche Langversion der Leitlinie. 


\section{Guideline Program}

\section{Editors}

Leading Professional Medical Associations

\section{5}

German Society of Gynecology and Obstetrics (Deutsche Gesellschaft für Gynäkologie und Geburtshilfe e. V. [DGGG])

Head Office of DGGG and Professional Societies Jägerstraße 58-60, DE-10117 Berlin info@dggg.de

http://www.dggg.de/

\section{President of DGGG}

Prof. Dr. med. Anton Scharl

Direktor der Frauenkliniken

Klinikum St. Marien Amberg

Mariahilfbergweg 7, DE-92224 Amberg

Kliniken Nordoberpfalz AG

Söllnerstraße 16, DE-92637 Weiden

\section{DGGG Guidelines Representatives}

Prof. Dr. med. Matthias W. Beckmann Universitätsklinikum Erlangen, Frauenklinik Universitätsstraße 21-23, DE-91054 Erlangen

Prof. Dr. med. Erich-Franz Solomayer Universitätsklinikum des Saarlandes Geburtshilfe und Reproduktionsmedizin Kirrberger Straße, Gebäude 9, DE-66421 Homburg

\section{Guidelines Coordination}

Dr. med. Paul Gaß, Christina Meixner Universitätsklinikum Erlangen, Frauenklinik Universitätsstraße 21-23, DE-91054 Erlangen leitlinien@dggg.de http://www.dggg.de/leitlinienstellungnahmen

Stand: Dezember 2020

\section{OEGGG}

Austrian Society of Gynecology and Obstetrics (Österreichische Gesellschaft für Gynäkologie und Geburtshilfe [OEGGG])

Frankgasse 8, AT-1090 Wien stephanie.leutgeb@oeggg.at http://www.oeggg.at

President of OEGGG

PD Dr. med. Gunda Pristauz-Telsnigg

Universitätsklinik für Frauenheilkunde und Geburtshilfe

Klinische Abteilung für Gynäkologie

Auenbruggerplatz 14, A-8036 Graz

\section{OEGGG Guidelines Representatives}

Prof. Dr. med. Karl Tamussino

Universitätsklinik für Frauenheilkunde und Geburtshilfe Graz Auenbruggerplatz 14, AT-8036 Graz

Prof. Dr. med. Hanns Helmer Universitätsklinik für Frauenheilkunde Wien Währinger Gürtel 18-20, AT-1090 Wien

\section{gynécologie}

Swiss Society of Gynecology and Obstetrics (Schweizerische Gesellschaft für Gynäkologie und Geburtshilfe [SGGG])

Gynécologie Suisse SGGG

Altenbergstraße 29, Postfach 6, CH-3000 Bern 8

sekretariat@sggg.ch

http://www.sggg.ch/

President of SGGG

Dr. med. Irène Dingeldein

Längmatt 32, CH-3280 Murten

SGGG Guidelines Representatives

Prof. Dr. med. Daniel Surbek

Universitätsklinik für Frauenheilkunde

Geburtshilfe und feto-maternale Medizin

Inselspital Bern

Effingerstraße 102, CH-3010 Bern

Prof. Dr. med. René Hornung

Kantonsspital St. Gallen, Frauenklinik

Rorschacher Straße 95, CH-9007 St. Gallen 